\title{
BANDOS URBANOS Y PACIFICACIÓN SEÑORIAL EN LA CASTILLA BAJOMEDIEVAL: PAREDES DE NAVA Y FERNANDO DE ANTEQUERA $(1400-1416)^{1}$
}

\author{
URBAN FACTIONS AND SEIGNIORIAL PACIFICATION \\ IN LATE MEDIEVAL CASTILE: \\ PAREDES DE NAVA AND FERNANDO OF ANTEQUERA \\ (1400-1416)
}

\author{
VÍCTOR MUÑoz GóMEZ \\ Universidad de Valladolid
}

Resumen: En este artículo nos acercamos a la función desempeñada por el poder señorial en situaciones de conflicto que enfrentaban a los vasallos bajo su dominio y afectaban al ejercicio de su autoridad. Hemos tomado como ejemplo el conflicto entre bandos por el gobierno concejil desarrollado entre 1401 y 1403 en la villa castellana de Paredes de Nava, lugar de señorío del infante Fernando de Antequera. A partir del mismo, podemos observar la diversidad de factores que condicionaban este tipo de pugnas y la sofisticación de los mecanismos desplegados por la instancia señorial para afrontarlas. Como veremos, discurso y acción señoriales se articulan en una combinación de justicia, paz, imposición y mediación.

Palabras clave: Señorío; Conflicto; Bando urbano; Pacificación; Paredes de Nava; Infante Fernando de Antequera; Castilla; Siglos XIV y XV.

\begin{abstract}
This article approaches to the function carried out by the seigniorial poweraround situations of conflict which brought its vassals face to face and affected its exercise of authority. We analyse as an example the struggle between urban factions for the counciliar government happened in Paredes de Nava, a seigniorial town upon the infante Fernando of Antequera, in 1401-1403. In base of this case, we can observe that these clashes were conditioned by a great variety of factors and the remarkable sophistication of resources deployed by the seigniorial sphere for facing them. As we could see, justice, peace, imposition and mediation are finely articulated into seigniorial speech and action.
\end{abstract}

Keywords: Lordship; Conflict; Urban faction; Pacification; Paredes de Nava; "Infante" Fernando of Antequera; Castile; 14th-15th centuries.

\footnotetext{
${ }^{1}$ Este trabajo ha sido realizado a partir del disfrute de una beca/contrato de postgrado del Programa Nacional de Formación de Profesorado Universitario del Ministerio de Educación y Ciencia, referencia AP-2004-5182.

El presente artículo es la plasmación escrita de algunas de las ideas planteadas durante mi intervención en el coloquio internacional organizado por la Dra. $\mathrm{M}^{\mathrm{a}}$. Teresa Ferrer y Mallol en la Institució Milà i Fontanals (CSIC) los dias 4 y 5 de octubre de 2007 Conflictivitat $i$ vies de solució a la Mediterrània medieval. Aprovecho la ocasión para agradecer a la Dra. Roser Salicrú i Lluch la propuesta que me hizo para participar en esta reunion científica y, por supuesto, la invitación expresa de la Dra. Ferrer i Mallol para colaborar en la misma. Quiero hacer extensivo mi agradecimiento a todo el personal del Departamento de Estudios Medievales de la Institució Milà i Fontanals por su acogịda y apoyo durante los meses que tuve el placer de compartir con ellos en Barcelona, con especial atención a la Dra. Salicrú, quien tuvo la amabilidad de guiar mis pasos allí.
} 


\section{SUMARIO}

1. Introducción.- 2. El conflicto de 1401-1403.- 3. La actitud señorial ante el conflicto. Factores condicionantes.- 4. Mecanismos de acción señorial ante el conflicto. Información, negociación e imposición.- 5 . Balance de fuerzas entre los poderes locales y el sistema señorial tras la concordia de 1403.- 6. Conclusiones.- 7. Apéndice documental.

\section{INTRODUCCIÓN}

Es bien sabido como la publicación en 1975 por el profesor Julio Valdeón de su libro Los conflictos sociales en el reino de Castilla en los siglos $X I V$ y $X V$ supuso, prácticamente, la introducción en el Medievalismo hispano de la línea de investigación historiográfica centrada en la problemática de la conflictividad social ${ }^{2}$. Ya desde sus inicios, la preocupación por los choques de carácter estructural entre grupos sociales dominantes y dominados ha conducido a que los conflictos antiseñoriales hayan sido objeto de gran atención entre los estudiosos de la Castilla bajomedieval ${ }^{3}$. De hecho, lo cierto es que los especialistas que se han ocupado de la nobleza y los señoríos bajomedievales castellanos desde diferentes posicionamientos teóricos no han dejado de atender a los enfrentamientos entre los señores y los vasallos sometidos a su dominio ${ }^{4}$.

Con este trabajo, desde un enfoque un tanto diferente al de esa perspectiva más habitual, pretendemos realizar una nueva aportación a este interesante campo de análisis historiográfico. Sí nos interesa llamar la atención sobre contextos conflictivos relativos a ámbitos de dominación señorial. En cambio, proponemos una aproximación al papel desempeñado por los señores en otro tipo de enfrentamientos en que su participación en ellos ha sido de

\footnotetext{
${ }^{2}$ Julio VALDEÓN BARUQUE, Los conflictos sociales en el Reino de Castilla en los siglos XIV y $X V$, Madrid, 1975. Esta monografía se vio precedida ese mismo año por su artículo Movimientos antiseñoriales en el siglo XIV, "Cuadernos de Historia" (Anexos de la Revista Hispania), 6 (1975), pp. 357-390.

${ }^{3}$ Listar una bibliografía medianamente completa no procede en este lugar ante el torrente de trabajos surgidos en los últimos treinta años. Baste citar algunos títulos tan ilustrativos como Salustiano MORETA VELAYOS, Malhechores feudales. Violencia, antagonismos y alianzas de clases en Castilla, siglos XIII-XIV. Madrid 1977; Carlos BARROS, Mentalidad justiciera de los irmandiños (siglo XV), Madrid, 1990; Emilio CẢBRERA y Andrés MOROS, Fuenteovejuna. La violencia antiseñorial en el siglo XV', Barcelona, 1991; E. CABRERA, Conflictos en el mundo rural. Señores y vasallos, en José Ignacio de la IGLESIA DUARTE (coord.), Conflictos sociales, políticos e intelectuales en la España de los siglos XIV y XV, "XIV'Semana de estudios medievales. Nájera 2003”, Logroño, 2004, pp. 49-80; o Hipólito Rafael OLIVA HERRER, Justicia contra señores. El mundo rural y la política en tiempos de los Reyes Católicos, Valladolid, 2004.

${ }^{4}$ No existe monografía dedicada a un estado señorial que no incluya un capítulo relativo a estos conflictos y la cantidad de artículos y contribuciones a reuniones científicas sobre este tipo de temas resulta inabarcable. Valga como ejemplo remitir a los cuatro volúmenes de Esteban SARASA SÁNCHEZ y Eliseo SERRANO MARTín (eds.), Señorío y feudalismo en la Península Ibérica (ss. $X I I-X I X)$, Zaragoza, 1993, resultado del magno congreso celebrado en 1990 para el estudio del régimen señorial en la Penínsụla Ibẹ́rica. La dedicación de la quinta sec̣ción del encuẹtro científico a la conflictividad antiseñorial es una buena muestra del lugar capital que la oposición entre señores y vasallos ocupa para la historiografía en el estudio del régimen feudal (Vol. II, pp. 319-419; Vol. IV, pp. 11-174).
} 
primera relevancia sin responder al de ser uno de los contendiente antagonistas en los mismos. Nos referimos a aquellas situaciones en que las estructuras de poder señorial ejercieron funciones de mediación, arbitraje y resolución en pugnas que enfrentaron a distintos agentes socio-políticos sometidos a la autoridad de tales estructuras.

Así, la potestad jurisdiccional de los señores en la Castilla bajomedieval, en tanto transmitida por delegación por la Corona, implicaba la entrega de todos los derechos propios de la Monarquía, salvo aquellos especificados en los propios documentos de donación del señorío que respondían a ese principio de "mayoría de justicia" sobre el que se sostenía la soberanía regia". El ejercicio del gobierno y de la justicia sobre el territorio y las personas sujetos al señorío que, entre otras facultades, implicaba ese derecho jurisdiccional, otorgaba a los señores la capacidad de intervenir ante situaciones de enfrentamiento entre los vasallos de sus dominios que afectasen al mantenimiento de la paz y la justicia dentro de ellos para su enmienda y conservación. O lo que es lo mismo, para la guarda y restauración del serviçio de Dios y del rey, bien común, y pro del reino - o del señor, de la ciudad o la villa, del lugar, u otra cualquier agencia de dominación política a la que refiriese el discurso-, fundamentos teóricos sobre los que se sostenía la idea de buen gobierno sobre la comunidad política del reino, de los que participa, lógicamente, el orden señorial como instancia intermedia de poder entre el Rey y el regnum ${ }^{6}$. En último término, de lo que hablamos es de acción en defensa del orden establecido en el espacio señorializado, un principio clave para la consecución de los objetivos perseguidos por sus titulares respecto a estos dominios: un gobierno estable y reconocido sobre los lugares que componían los estados señoriales en la Castilla bajomedieval en términos de control político de la población y el espacio, de orden social interno, de eficiencia hacendística y disponibilidad militar ${ }^{7}$.

${ }^{5}$ José Luis BERMEJO CABRERO, Mayoría de justicia del rey y jurisdicciones señoriales en la Baja Edad Media castellana, en "I Is Jornadas de Metodología aplicada a las Ciencias Históricas. Volumen II", Santiago de Compostela, 1975, pp. 191-206; María Concepción QUINTANILLA RASO, El estado señorial nobiliario como espacio de poder en la Castilla bajomedieval, en J.I. de la İGLESIA DUARTE (coord.), Los espacios de poder en la España Medieval, "XII Semana de Estudios Medievales. Nájera 2001", Logroño, 2002, pp. 245-314, en concreto, pp. 262-269.

${ }^{6}$ Sobre las bases del poder monárquico, véase José Manuel NIETO SORIA, Los fundamentos ideológicos del poder real en Castilla (siglos XIII-XVI), Madrid, 1988; IDEM, El reino: la monarquía bajomedieval como articulación ideológica, en J.I. de la IGLESIA DUARTE (coord.), Los espacios de poder en la España Medieval, cit. pp. 341-370. La comparación del caso castellano con otros del Occidente medieval evidencia la comunidad en torno a los principios enumerados (Bernard GUENÉE, Occidente en los siglos XIV y XV. Los Estados, Barcelona, 1973, pp. 46-50; Anthony BLACK, El pensamiento político en Europa, 1250-1450, Cambridge, 1996, pp. 20-62 y 211-228, con especial atención al concepto de bien común en las pp. 36-42.).

${ }^{7}$ Sobre la definición del régimen señorial en la Castilla bajomedieval y, el desarrollo de los aparatos de poder en los estados señoriales nobiliarios de la época, José María MONSALVO ANTÓN, Poder político y aparatos de estado en la Castilla bajomedieval. Consideraciones sobre su problemática, "Studia Historica. Historia Medieval", IV-2 (1986); Isabel BECEIRO PITA, Los estados señoriales como estructuras de poder en la Castilla del siglo XV, en Adeline RUCOUOI (coord.), Realidades e imágenes del poder. España a fines de la Edad Media, Valladolid, 1988, pp. 293-323; Paulino IRADIEL MURUGARREN, Señoríos jurisdiccionales y poderes públicos a finales de la Edad Media, en "XXIII Semana de Estudios Medievales. Estella, 22-26 de julio de 1996": Poderes públicos en la Europa Medieval: Principados, Reinos y Coronas, Pamplona, 1997, pp. 69-116; Ma . C. QUINTANILLA RASO, El estado señorial, cit. 
El señorío bajomedieval castellano, extendido característicamente sobre un importante número de ciudades y villas en toda la Corona ${ }^{8}$, hubo de operar sobre estructuras concejiles ciertamente complejas, dotadas de una fuerte personalidad política de comunidad sostenida sobre arraigadas tradiciones jurídicas e institucionales, en las que la competencia y el equilibrio por la preeminencia social y económica en el ámbito local enfrentaba a distintos actores, tanto elites municipales como bases sociales pecheras, por la concurrencia al concejo y el control político del mismo, a menudo de forma abierta y cruenta ${ }^{9}$. Conviene, pues, preguntarnos acerca de cómo los sistemas de poder señoriales, particularmente aquellos encabezados por linajes nobles ${ }^{10}$,

${ }^{8} \mathrm{Al}$ calor de los efectos de la crisis del siglo XIV y de los pasos de la Monarquía hacia un régimen estatal centralizado de base autoritaria, se produjo una profunda redefinición y expansión del régimen señorial en Castilla en los siglos bajomedievales. En torno a este complejo proceso y su percepción global, me permito remitir a los trabajos citados en la nota anterior, muy concretamente a los de J.M ${ }^{a}$. MONSALVO ANTÓN, Poder político y aparatos de estado, cit., pp. 106-114; y P. IRADIEL MURUGARREN, Señoríos jurisdiccionales, cit. pp. 84-93. Igualmente, una síntesis reciente en J.M ${ }^{\mathrm{a}}$. MONSALVO ANTÓN, Historia de España 3er Milenio La baja edad media en los siglos XIV-XV. Política y cultura, Madrid, 2000, pp. 15-74 y 115-154; y las lúcidas reflexiones en torno a los orígenes de la señorialización en relación con la definición del poder real en tanto "Señorío del Rey", el desarrollo de los aparatos de Estado de la Monarquía castellano-leonesa y la pervivencia de las relaciones feudales en los siglos XIII-XIV en Carlos ESTEPA DíEZ, La Monarquía castellana en los siglos XIII-XIV. Algunas consideraciones, "Edad Media. Revista de Historia", 8 (2007), pp. 79-98.

${ }^{9} \mathrm{La}$ abundancia de trabajos sobre la complejidad política del mundo urbano castellano en la Baja Edad Media es más que evidente (María ASENJO GONZÁLEZ Las ciudades medievales castellanas. Balance y perspectivas de su desarrollo historiográfico (1990-2004), "En la España medieval", 28 (2005), pp. 415-453). Valgan para ilustrar las dinamicas propias de este subsistema de poder y'de los distintos agentes integrados en él, amén del debate existente al respecto de estos conceptos y elementos: J.M ${ }^{\mathrm{a}}$. MONSALVO ANTÓN, Poder político y aparatos de estado, cit.; IDEM, El Sistema político concejil: el ejemplo del señorio medievál de Alba de Tormes y su concejo de villa y tierra, Salamanca, 1988; IDEM, Vertebración jurídica de los concejos castellanos de la meseta durante la época del régimen medieval: la distribución social del poder. en Concejos y ciudades en la Edad Media hispánica "II Congreso de Estudios Medievales. Fundación Sănchez-Albornoz", León, 1990, pp. 357-428; IDEM, Historia de los poderes medievales, del Derecho a la Antropología (el ejemplo castellano: monarquía concejos y señoríos en los siglos XII-XV), en C. BARROS (ed.)., "Historia a debate. Medieval", Santiago de Compostela, 1995, pp.81-149; Ma . ASENJO GONZÁLEZ, Sociedad y vida política en las ciudades de la Corona de Castilla: Reflexiones sobre un debate "Medievalismo", 5 (1995), pp. 89-126 María Isabel del VAL VALDIVIESO, Aspiraciones y actitudes socio-políticas. Una aproximación a la sociedad urbana de la Castilla bajomedieval, en Juan Antonio BONACHÍA HERNANDO (coord.), La ciudad medieval. Aspectos de la vida urbana en la Castilla bajomedieval, Valladolid, 1996.

${ }^{10}$ La definición del concepto "sistema político concejil" como subsistema dentro de una estructura de poder englobadora mayor correspondiente al conjunto del reino como resultado de la aplicación metodológica de la teoría general de sistemas al anălisis de las instancias y relaciones de poder dentro de la esfera municipal castellana (J.M ${ }^{\text {a }}$. MONSALVO ANTóN, El Sistema político concejil, cit. en concreto, pp. 133-141, 265-359), nos conduce, como consecuencia lógica de esta percepción sistémica, a su aplicación para el estudio de los aparatos señoriales, entenđidos como estadio intermedio de las relaciones de poder entre Rey y reino (J.M ${ }^{\text {a }}$. MONSALVO ANTÓN, Historia de España 3er. Milenio, cit., pp. 115-154; M $^{\mathrm{a}}$. C. QUINTANILLA RASO, El estado señorial, cit., pp. 258-269, 285-314). Por ello, me permito proponer la noción de "sistema de poder señorial" como una herramienta conceptual y metodologica útil para definir y estudiar de un modo integral las características y el funcionamiento de tales complejos situados en esa posición intermẹdia en las relaciones generales de poder, entre la Corona y la comunidad concejil autónoma - ciudad, villa o lugar-, integrados jerárquicamente por diferentes personas, instituciones y patrimonios en torno a la jefatura de un individuo o colectividad. Aplicable a toda suerte de señoríos, se antoja particularmente útil de cara a afrontar una observación totalizadora de las estructuras de este tipo desarrollados por los grupos parentelares linajísticos de la nobleza, a partir de la percepción oikonómica de los grupos humanos y los recursos materiales organizados alrededor de una familia bajo el liderazgo de un pater familias, cabeza de linaje. Sobre la teoría antropológica de la Oikonómica, Otto BRUNNER, La "casa grande" y la "oeconomica” de la Vieja Europa, en Nuevos caminos de la historia social e institucional, Buenos Aires, 1976, pp. 88-99. Para su actualización y aplicación historiográfica en el ámbito hispano, Ignacio ATIENZA 
afrontaron de un modo efectivo los conflictos desatados en los medios urbanos bajo sus jurisdicciones, en los cuales no eran - al menos, en un principio uno de los agentes en pugna y sin embargo se veían irremisible pero necesariamente implicados, por cuanto competían a sus potestades y podían afectar o incluso amenazar tanto a éstas como a sus intereses en términos de gobernabilidad y extracción de renta y recursos.

Una de las más típicas manifestaciones de estas oposiciones en el seno de la sociedad urbana castellana fueron los enfrentamientos por el control del poder urbano y de sus resortes institucionales entre los individuos que integraban el sector más prominente de aquella, a menudo organizados en diferentes formas de partidos o bandos ${ }^{11}$. El desarrollo de nuestras investigaciones sobre el estado señorial y el entorno clientelar del infante Fernando de Antequera y de su esposa Leonor de Alburquerque nos ha ofrecida la posibilidad de acercarnos a un, como veremos, muy particular ejemplo de este tipo de conflictos, documentado en la villa de Paredes de Nava (actual provincia de Palencia) entre 1401 y 1403, a la sazón lugar de señorío del infante Fernando de Antequera y de Leonor de Alburquerque. Éste ya había sido objeto de estudio con anterioridad ${ }^{12}$ y recientemente tuvimos ocasión de volver sobre él monográficamente en relación a la problemática de las formas de concurrencia política de las elites urbanas en la Castilla bajomedieval ${ }^{13}$. Nuestro objetivo en este artículo se basa en buena medida en la labor ya realizada en estos trabajos citados de caracterización de la naturaleza del enfrentamiento entre las facciones en que quedaron encuadradas las elites locales de la Paredes de Nava, de los protagonistas del mismo y de los objetivos perseguidos por las partes en litigio. Este sería, precisamente, tratar de discernir las preocupaciones despertadas por el estallido del dicho conflicto en la esfera señorial, las actitudes al respecto de los señores y los mecanismos desplegados por ese poder superior para tratar de encauzar y atajar una lucha contraria a sus propósitos. La percepción de conjunto nos colocará, en último término, en disposición de atender un sugerente cuadro de la dinámica

HERNÁNDEZ, Pater familias, señor y patrón: oeconomía, clientelismo y patronato en el Antiguo Régimen, en Reyna PASTOR DE TOGNERI (comp.), Relaciones de poder, de produccion y parentesco en la Edad Media y Moderna, Madrid, 1990, pp. 411-458.

${ }^{11}$ Véase a modo de introducción el que fue un trabajo pionero en este sentido (Miguel Ángel LADEROQUESADA, Linajes, bandos y parcialidades en la vida politica de las ciudades castellanas (siglos XIV y XV), en Bandos y querellas dinásticas en España al final de la Edad Media "Actas del Coloquio celebrado en la Biblioteca de España de París en mayo de 1987”, París, 1991, pp. 105-134), además de las obras citadas en la nota anterior. Tendremos ocasión de volver sobre este tema con mayor profundidad más adelante.

${ }^{12}$ J.C. MARTÍN CEA, El mundo rural castellano a fines de la Edad Media. El ejemplo de Paredes de Nava en el siglo XV. Valladolid, 1991, pp. 48-53; IDEM, Poderes públicos y sociabilidad local en la villa de Paredes de Nava en el Cuatrocientos, en J.A. BONACHÍA HERNANDO, (coord.), La ciudad medieval, cit., pp. 255-316, en concreto, pp. 292-293; IDEM, Violencia y conflictividad social en Castilla, vista desde el prisma de la historia local (siglos XIV y $X V$ ) en José Antonio MUNITA LoINAZ (ed.), Conflicto, violencia y criminalidad en Europa y América, "IV Jornadas de Estudios Históricos del Departamento de Historia Medieval, Moderna y de América (Vitoria-Gasteiz, 11 al 13 de noviembre de 2002)", Vitoria, 2004, pp. 129-130.

${ }^{13}$ Víctor MUÑOZ GóMEZ, La participación política de las elites locales en el gobierno de las ciudades castellanas en la Baja Edad Media. Bandos y conflictos de intereses (Paredes de Nava. final del siglo XIV-inicio del siglo XV), "Anuario de Estudios Medievales", 39/1 (2009), pp. 275305 . 
relacional establecida normalmente entre los elementos políticos del sistema concejil y las instancias del sistema señorial. Ésta, como veremos, contempla, dependiendo de los factores en juego, muchas más opciones que la simple y directa imposición desde arriba.

\section{EL CONFLICTO DE 1401-1403}

Aunque, como veníamos señalando, el relato de los acontecimientos que caracterizaron el enfrentamiento banderizo que, entre 1401 y febrero de 1403 , protagonizaron distintos sectores de la elite social de la villa terracampina por el control del poder municipal ya ha sido intensamente abordado, no podemos dejar de presentar sus líneas básicas para una mejor concreción del asunto que aquí proponemos desgranar ${ }^{14}$. Para ello, hemos de partir del año 1400 , cuando tras la muerte del señor del lugar, don Pedro, conde de Trastámara, su hijo y heredero, don Fadrique, acordó el trueque de la misma con el infante don Fernando y su esposa, Leonor de Alburquerque, a cambio de Ponferrada, Villafranca del Bierzo (actual provincia de León) y El Barco de Valdeorras (actual provincia de Orense), en el Bierzo y Galicia ${ }^{15}$.

Cuando, al año siguiente, el infante procedió a tomar posesión de su nuevo dominio ${ }^{16}$, el concejo de Paredes aprovechó para elevar una petición a su nuevo señor con el fin de que los oficios municipales, hasta entonces repartidos entre dos facciones integradas por parte de los potentados locales, dejasen de ser elegidos de este modo a través de la pertenencia a cada uno de los bandos ${ }^{17}$. Como era previsible, este golpe de mano no fue bien aceptado por las facciones y hasta julio de 1402 se sucedieron diferentes movimientos ante la Corte señorial con el fin de restituir la situación anterior, los cuales, pese a ser atendidos por el infante Fernando, fueron ignorados por el concejo. El bloqueo de la situación condujo a que, finalmente, desde la Corte señorial se tomara la decisión de comisionar a Sancho Fernández, el moço, vecino de

\footnotetext{
${ }^{14}$ En cualquier caso, para un conocimiento más detallado del mismo, remitimos a las referencias bibliográficas apuntadas en las notas 12 y 13 .

${ }^{15}$ Sobre este asunto, véase V. MUÑOZ GÓMEZ, La adquisición de dominios señoriales en la Castilla Bajomedieval. Fernando de Antequera y Paredes de Nava (1380-1408) en "III Simposium Internacional de Jóvenes Medievalistas, Lorca, 2006", Murcia, 2008, pp. 121-132.

${ }^{16}$ Archivo Municipal de Paredes de Nava (AMPdN), Cuentas de Propios (CP), Borradores, 236/16, f. 62/03 r. 1401; CP, 238/03, ff. 02/03 r., 04 r., 06 v., 07 r.-08 r., 1401. Estas anotaciones en los libros de cuentas del concejo se refieren a gastos desprendidos en la recepción del infante Fernando de Antequera para la toma de posesión del lugar (mensajeros, derechos de entrada, festejos, etc.) y que, por desgracia, por su falta de data impiden conocer el momento concreto en que el infante tomó posesión de Paredes.

${ }^{17} \mathrm{AMPdN}$, CP, Borradores, 236/16, ff. 62/04 r. 07 r. y v. 13 v., 27 v., 56 r., 1401; Cuentas de Propios, 238/02, f. 01/01 r., s.a. [1401]; 238/03, ff. 022/06 v, 07 v.,, 09 v.,, 14 v., 1401. La referencia textual a la petición se refería a “...quel dicho conçeio nombrase los ofiçiales e non fuesen los que eran nombrados de vando a vando, e ganóse esta carta”. Estas anotaciones contables paredeñas tocantes a las gestiones para ganar esta provisión sobre el nombramiento de los oficiales concejiles, no cuentan, igualmente con data. Todo apunta a que las primeras reuniones del concejo sobre esta cuestion y la audiencia ante el infante sobre este negocio en Villalón (actual provincia de Valladolid), donde se ganó la carta, fueron previas a la visita del señor y que el asunto quedó definitivamente despachado en la Corte de don Fernando en Medina del Campo después de la toma de posesión referida.
} 
Medina del Campo (actual provincia de Valladolid) y vasallo del infante, como corregidor en la villa ${ }^{18}$. Siendo su potestad enmendar los asuntos entendidos como contrarios a justicia respecto a los oficiales concejiles de años pasados, fue inmediatamente acogido por los representantes de ambos partidos, pero el concejo se negó a aceptarlo en su cargo ${ }^{19}$.

Las protestas presentadas por los emisarios del concejo a causa de la presencia del corregidor en Medina del Campo ante el infante fueron, no obstante, en vano. Éstos fueron encarcelados por orden del señor y sólo gracias a la mediación de algunos de los oficiales del infante Fernando pudieron ser liberados, una vez el concejo aceptó, resignado, someterse a reconocer la autoridad del corregidor ${ }^{20}$. Durante los meses siguientes, las maniobras emprendidas por los agentes señoriales se centraron en la resolución del conflicto existente, que sin embargo se hallaba oscurecido por la enemistad existente entre don Fernando, uno de los hijos de don Alfonso, conde de Noreña y señor de Paredes de Nava entre 1372 y 1383, y cabecilla de uno de los bandos, y toda una serie de vecinos de la villa, que habían sido objeto de una serie de abusos cometidos por aquél, particularmente el asesinato de algunos parientes suyos ${ }^{21}$. Tras diversas negociaciones entre las partes en litigio, de las cuales permaneció completamente informado Fernando de Antequera, entre el 1 y el 11 de febrero de 1403, miembros de ambos bandos se desplazarían a la Corte señorial en Medina, donde finalmente acordarían una pacificación y concordia ante el señor que saldaba todos los conflictos preexistentes ${ }^{22}$. Poco después, resueltos los desórdenes para los que había sido nombrado el corregidor Sancho Fernández, éste concluyó su oficio

${ }^{18}$ Éste se personó en Paredes de Nava el 28 de agosto de 1402 (AMPdN, CP, 238/01, f. 90/05 r., s.a. [1402]-VIII-28), con posterioridad a las últimos negocios movidos por gentes de la villa respecto al asunto del reparto de oficios (AMPdN, CP, 238/04, f. 03/06 r., 1402: asiento de 5 florines por la carta que trajeron sobre los oficiales Juan García Tablares y Juan García Mazón, en julio de 1402).

${ }^{19}$ AMPdN, Carpeta 01, no 50 (Signatura Antigua), 1402-VIII-28, lunes-VIII-30, miércoles, Paredes de Nava. Este documento, la copia conservạda por el concejo de la respuesta dada al corregidor para no recibirlo en su oficio, tras la última ordenación del Archivo Municipal de Paredes de Nava en los años 90 del pasado siglo XX, se halla en paradero desconocido. Quiero agradecer al profesor Juan Carlos Martín Cea que me haya facilitado la consulta de una copia que él mismo pudo tomar del dicho instrumento, el cual transcribo (ver apéndice documental).

${ }^{20}$ Sobre el apresamiento de Jụan García Tablares y Fernán Martínez, bachiller, alcalde de la villa, representantes del concejo, AMPdN, CP, 238/04, f. 03/07 r., 1402 . Respecto a las
gestiones para su liberación a las que contribuyeron el propio corregidor, Alfonso Fernández de las Eras, alcaide de la fortaleza de Paredes por el infante, y Alvaro de Avila, camarero del señor, AMPdN, CP, 238/01, ff. 90/05 v.-06 v., S.a. [1402]. Trạs ella, en efecto, Sancho Fernández no volvió encontrar obstáculos para el ejercicio de sus funciones.

${ }^{21}$ Sobre el protagonismo por don Fernando de Noreña en la villa palentina y su relación con la articulación de las facciones locales, véase particularmente V. MUNOZ GómEZ, La participación política, cit., pp. 295-298.

${ }^{22}$ Sobre las distintas negociaciones entre los bandos, AMPdN, CP, 238/04, ff. 03/03 r., 08 r., 1402; 238/05, f. 04/08 V.. 14 r., 1403. Respecto a las últimas vistas habidas en Medina del Campo y la concordia, AMPdiN, C.P. ., Borradores, 236/18, ff. 64/10 r.-13 v., 19 r.-23 v., 1403; C.P., 238/05, ff. 04/19 r., 22 r., 29 r.-39 r., 1403. 
y abandonó la villa entre los agradecimientos a él obsequiados por el concejo de Paredes de Nava ${ }^{23}$.

\section{LA ACTITUD SEÑORIAL ANTE EL CONFLICTO. FACTORES CONDICIONANTES}

De acuerdo a esta presentación de los acontecimientos, podemos preguntarnos sobre el papel desempeñado en el mismo por su otro protagonista junto con los propios contendientes en el conflicto: el aparato de poder señorial. En efecto, la acción de las distintas instancias del sistema de poder señorial, encabezado por infante Fernando y a su servicio, resultó clave de cara al apaciguamiento y resolución del enfrentamiento en la villa. Por ello, a la hora de comenzar a analizar la posición adoptada por la instancia señorial, hemos de interrogarnos sobre la perspectiva desde la que esta autoridad enfrentó la situación problemática en que se vio embarcada y los factores condicionantes bajo los que se desarrolló esta implicación.

En este sentido, podemos distinguir tres momentos diferentes a lo largo del enfrentamiento estudiado. Primeramente, desde su inicio en 1401 hasta julio-agosto de 1402, en que la iniciativa sobre el nombramiento de los oficios concejiles en Paredes de Nava correspondió a los agentes locales directamente concernidos por ello - concejo y bandos- y la acción señorial tuvo un carácter, si no pasivo, sí limitado a atender los requerimientos dispares presentados desde la villa. Seguidamente, esta actitud alcanzó su punto de inflexión entre julio-agosto de 1402, cuando el infante Fernando decidió tomar la iniciativa ante la continuación del problema mediante el definitivo envío de un corregidor a la villa, y durante un tiempo no bien determinado pero que no fue más allá de septiembre o, a lo sumo, octubre de 1402 , correspondiente al momento de la protesta del concejo por la llegada de Sancho Fernández a la villa y a la consiguiente prisión y posterior liberación de los delegados concejiles comisionados a la Corte señorial en Medina del $\mathrm{Campo}^{24}$. Finalmente, tras la ratificación de la decisión señorial sobre el corregidor y la sumisión del concejo a su autoridad, reflejadas en el cautiverio y posteriores gestiones para la puesta en libertad de los emisarios paredeños, a lo largo del final de 1402 y hasta febrero de 1403, nos encontraríamos con ese último momento, protagonizado por la iniciativa señorial encaminada a fomentar una solución pactada entre las fuerzas en conflicto dentro de la villa

\footnotetext{
${ }^{23} \mathrm{AMPdN}, \mathrm{CP}, 238 / 05$, f. 04/18 r., 1403: asiento de 2.000 maravedís (mrs.) que se entregaron a Sancho Fernández, el moço, como regalo "por el vien que fizo a esta villa por la poner en paz". Estas últimas menciones a este personaje no son posteriores a febrero de 1403.

${ }^{24} \mathrm{Si}$ la llegada del corregidor se produjo el 29 de septiembre, habría que suponer una reacción por parte del concejo poco posterior a esta fẹcha. La misión de Juan García Tablares y el bachiller Fernán Martínez, que supuso su apresamiento y posterior liberación, hubo de durar entre 12 y tal vez más de 17 días, a razón de los 5 y 12 días de trabajo que pagó el concejo a dos hombres que fueron a servirles a Medina del Campo (AMPdN, CP, 238/01, ff̣. $90 / 05 \mathrm{v} .-06 \mathrm{v}$. s.a. [1402]). De ello deducimos que, a lo sumo, la puesta en libertad de los emisarios se produjo en octubre de 1402 .
} 
y que, efectivamente, concluiría con la firma de la concordia entre bandos en la Corte de Medina y la finalización del oficio del corregidor Sancho Fernández. Como podemos apreciar, existió una marcada evolución de la posición señorial, desde una inicial implicación limitada, en forma de distintas ordenanzas correctoras surgidas de la petición por los agentes socio-políticos afectados, hasta una definitiva e intensa intervención directa, en virtud de la superioridad de la potestad jurisdiccional señorial, dirigida a la pacificación y arbitrio de las diferencias entre sus vasallos de Paredes de Nava. La comprensión de una serie de factores condicionantes puede ayudar a entender tanto esa primera posición, más bien prudente y poco autoritaria, como la última, mucho más resuelta y activa, respecto al ámbito concejil de dominio, y el tránsito de una a otra.

Así, en primer lugar, hemos de subrayar que la intromisión del elemento señorial dentro del conflicto de bandos paredeño no había partido de él mismo, sino que había surgido de los actores locales implicados en la pugna. Por una parte, el concejo, solicitando una ordenanza que regulase la elección de oficios, excluyendo de ella el reparto entre bandos de dichos oficios $^{25}$. Por la otra, los mismos bandos, que requirieron sucesivas revisiones de este mandato para restablecer el equilibrio de poderes entre ellos. Por un lado, restaurando su concurrencia a los cargos públicos; por el otro, garantizando una participación equitativa en los mismos, que denunciaba una de las facciones como quebrantada por la otra ${ }^{26}$. Este comportamiento, el recurso a la autoridad señorial para legislar con arreglo a justicia en un asunto relativo al gobierno urbano por parte del concejo y de las fuerzas políticas de

\footnotetext{
${ }^{25} \mathrm{AMPdN}, \mathrm{CP}, 238 / 02$, f. 01/01 r., s.a. [1401]; 238/03, ff. 02/06 v., 07 v., 1401. Ver nota 17.

${ }^{26}$ Tenemos constancia de esta serie de maniobras a partir del regesto conservado en el inventario del archivo municipal de Paredes de Nava realizado en 1820 del acta, hoy perdida, levantada por el concejo el 9 de junio de 1401 para la elección de nuevos oficiales a resultas de la oposicion de los miembros de los bandos a la ordenanza que les excluía del gobierno. En el susodicho se hace referencia a cómo se presentó carta del infante citando a otra carta suya en que mandaba "...que nombrasen en esta dicha su Villa oficiales de ambos los Vandos, tantos de una parte como de la otra", acordando "...que si en el repartir de los Oficios los Vandos no se aviniesen, nombrasen tales hombres que no fuesen de alguno de los Vandos..." y que volvieran a nombrar a los oficiales si ya lo hubieran hecho de un modo distinto a éste. Pero"...que hera querellado por parte de aquellos del un Bando, que fuera handaban, y por quienès se había requerido con dicha su carta, que no lo habían querido hacer según se les mandaba”. Por ello, el infante, "‥visto lo que por una y otra parte aclaró de varios Sugetos, que ante él fueron, y de quien reciviő Juramento en razón de aclarar quienes heran pertenecientes del Vando contrarios de los que fuera handaban para haber la mitad de los dichos oficios; e igualmente de los pertenecientes a el otro Vando; e hicieron el nombramiento por mitad, dos Alcaldes del uno y dos del otro, lo mismo con respecto a los demás Oficios, entre los cuales hay el de tener las Llaves del Sello del Concejo: dio por ninguno el anterior nombramiento, y que sirbiesen los electos ahora hasta Pascua de Resurrección del siguiente año, que hera la costumbre, reciviendo de ellos juramento". Aunque el concejo obedeció y cumplio tal mandato, no por elloọ dejó de protestar contra esta ordenanza, alegando ser contraria los fueros y privilegios de la villa, que incumplía al juramento que el infante hizo en su toma de posesión de Paredes de respetar aquéllos y que : $\ldots$ habiendo nombrado ellos los Oficiales en Hombres buenos, y llanos, sin vando, ni bullicio alguno, el Señor Ynfante los quitara", además de denunciar que algunas de las relaciones que recibió de los testigos el infante sobre los bandos eran falsas. (AMPdN,10026/03. Inventario General del Archivo. 1820. F. 47 r. y v. Doc. 145).

En este mismo sentido, AMPdN, CP, 238/02, f. 01/01 r., s.a. [1401]; 238/03, ff. 02/09 v., $14 \mathrm{~V}$., 1401; y J.C. MARTÍ́ CEA, El mundo rural, cit., pp. 48 -53 y 253-254; IDEM, Poderes públicos, cit., pp. 282-83 y 292-293; IDEM, Violencia y conflictividad, cit., pp.129-130.
} 
la villa supone, en efecto, el reconocimiento de la legítima potestad del señor sobre el lugar y sus habitantes. Ésta había sido cuestionada en Paredes de Nava durante los treinta años anteriores a la adquisición de la villa por el infante don Fernando, en forma de levantamiento antiseñorial en 1371 pero sobre todo a través de los intentos de vinculación al realengo de la villa que detectamos entre 1393 y 1399 -petición de retorno al realengo en 1393; acceso a la autoridad real ante los enfrentamientos con Fernando, hijo del conde de Noreña, entre 1396 y 1399 soslayando la agencia de poder señorial $^{27}$. La aceptación del señorío de Fernando de Antequera puede ligarse a la correspondencia que para la conciencia comunitaria de ser del Rey suponía la integración en el estado de quien por entonces era el infante heredero de la Corona, que, por tanto, habría facilitado que en Paredes de Nava se asumiese plenamente la potestad de la instancia señorial sobre la villa a partir de la toma de posesión del infante Fernando en $1401^{28}$.

Pero hemos de tener en cuenta que, pese al reconocimiento de esa autoridad, ésta podía verse afectada por una serie de limitaciones en el momento en el que se desató el conflicto. Precisamente, a causa de la inmediata entrada de Paredes de Nava en el señorío de Fernando de Antequera ese mismo año, el asentamiento del mismo en la villa era apenas superficial. Es cierto, en todo caso, y resulta necesario apuntarlo, que no hemos hallado rastros de una posible oposición al cumplimiento con las exigencias de la fiscalidad señorial durante los años en que se extendió el conflicto ${ }^{29}$. Pero, al tiempo, la presencia de oficiales de la administración señorial se restringía al alcaide de la fortaleza, Alfonso Fernández de las $\operatorname{Eras}^{30}$, y al recaudador del infante, Pedro García, hijo de Miguel Pérez ${ }^{31}$. Encargados de la guarda del alcázar de la villa y de la recepción de los impuestos requeridos por el infante, respectivamente, las competencias de éstos no implicaban capacidad decisoria

\footnotetext{
${ }^{27}$ Véanse, en este sentido, los párrafos a ello dedicados en V. MUÑOZ GóMEZ, $L a$ participación política, cit., pp. 284-286 y 296-298.

${ }^{28} \mathrm{El}$ concejo de Paredes entregó $600 \mathrm{mrs}$. al infante Fernando en calidad de infante heredero con motivo de su entrada en la villa para tomar posesión de ella (AMPdN, CP 238/03, f. 02/07 v., 1401). El infante Fernando fue heredero del trono hasta el nacimiento de la primera hija de su hermano Enrique III, la infanta María, el 14 de noviembre de 1401, jurada como heredera por las Cortes el 5 de enero de 1402 en Toledo (Fernando SUÁREZ BILBAO, Enrique III, Palencia, 2000 , pp. 223-224). La especificidad del tipo de señorío extendido sobre ciudades y villas entregadas por la Corona a reinas e infantes reales ya ha sido apuntada por algunos autores (I. BECEIRO PITA, Los dominios de la familia real castellana (1250-1350), en A. RUCQUOI (coord.), Génesis medieval del Estado Moderno. Castilla y Navarra (1350-1370)' Valladolid, 1987, pp. 79 106; pero sobre todo, Félix Javier MARTÍNEZ LLORENTE, Régimen jurídico de la Extremadura Castellana medieval. Las Comunidades de Villa y Tierra (s. X-XIV), Valladolid, 1990, pp. 309341 ), si bien resultaría procedente profundizar en el conocimiento de su especificidad y su funcionalidad de cara a la integración político-social de la parentela regia y a la propia definición del poder real.

${ }^{29}$ Sobre los capítulos de la fiscalidad señorial en Paredes, J.C. MARTín CEA, El mundo rural, cit., pp. 234-239. No obstante, los datos indicados en el gráfico de la página 237 sobre el pedido senorial han de ser revisados, al corresponder a 1401 y 1402 las cantidades de $20.000 \mathrm{mrs}$. cada año, de $30.000 \mathrm{mrs}$. en 1403, además de otros $40.000 \mathrm{mrs}$. que pidió el señor para las obras del puente de Alconétar (actual provincia de Cáceres) y 4.200 mrs. anuales de yantar y marzadga (AMPdN, CP, 238/03, f. 02/14 v., 1402; $238 / 05$, f. 04/12 v., 1403).
}

${ }^{30} \mathrm{AMPdN}, \mathrm{CP}$, Borradores, 236/16, f. 62/09 r., 1401.

${ }^{31} \mathrm{AMPdN}, \mathrm{CP}, 238 / 03$, f. 02/08 v., 1402. 
alguna dentro del concejo ${ }^{32}$. Además, presumible ambos eran vecinos de la villa y no hombres ligados al servicio de la Casa del infante con anterioridad a la adquisición del señorío de Paredes de $\mathrm{Nava}^{33}$. Más allá de estos dos individuos, no hemos podido hallar evidencias de que la red de clientes del infante Fernando se hubieran extendido entre individuos de la elite local ${ }^{34}$, por lo que hemos de considerar que las fidelidades con que podía contar el infante en la villa debían de ser más bien limitadas.

La debilidad del entramado clientelar del sistema señorial en la localidad, en consecuencia, afectaba a otro factor que a menudo no ha sido muy tenido en cuenta pero que registra una notoria importancia a la hora de analizar las relaciones de poder: la información. Aunque en los últimos años el estudio de la comunicación en la Edad Media ha sido objeto de atención por los investigadores, ante todo desde el punto de vista de la creación y difusión de discursos de carácter político en las sociedades de la época, aquí nos interesa incidir en ello desde otra perspectiva, concerniente al ejercicio efectivo del poder ${ }^{35}$. Nos referimos al acceso a una información concreta y veraz por partes de los agentes sociales de cara a configurar sus actuaciones en el medio en que se hallan insertos. Esto es, concretando para el contexto y caso que nos ocupa, a la capacidad que los aparatos señoriales en manos del infante Fernando tenían en Paredes de Nava para permanecer al corriente de los asuntos relativos a la administración de la villa y, a razón de este control de la información, para actuar en consecuencia con los objetivos planteados

${ }^{32}$ J.C. MARTín CEA, El mundo rural, cit., pp. 179-181.

${ }^{33}$ La mención de Pedro García como hijo Miguel Pérez, en las cuentas municipales, a țravés de una filiación con la que se entiende una persona conocida en el lugar, apunta hacia esa vecindad (ver nota 30), del mismo modo que la mención de Alfonso de las Eras ya en la contabilidad de 1396 señala en la misma dirección o, al menos, en un nexo con la villa previo a cualquier conexión con el infante Fernando (AMPdN, CP, Borradores, 236/11, ff. 57/06 r., 57/17 v., 1396).

${ }^{34}$ No hemos constatado la ostentación de oficios del sistema señorial por ningún paredeño ni la integración de alguno de los caballeros de la villa como vasallo del infante con tierras, acostamientos u otro tipo de mantenimiento a cambio de su servicio, como hombre de armas u otra función diferente, hasta 1408-1409, cuando tenemos noticias de Juan García de Paredes como tesorero del infante y de su lugarteniente Alfonso Mazón (AMPdN, CP, 230/10, f. 09/09 r. 1408; 238/11, ff. 10/21 v.-22 v., 1409), y no es hasta 1412 que hallamos noticia de un caballero, Juan García Tablares, al servicio de Fernando de Antequera con una lanza (AMPdN, CP, 239/01, f. $15 / 05 \mathrm{v} .1412$ ). Curiosamente, podría tratarse acaso del mismo personaje que fue enviado en octubre de 1402 junto con Fernán Martínez, bachiller, alcalde de la villa, como representantes del concejo a la Corte del infante Fernando para protestar contra el envío del corregidor Sancho Fernándéz a la villa, a resultas de lo cual fueron apresados (véanse notas 20 y 24), con todas las impliçaciones que ello tendría en términos de fidelización de la elite local por parte del poder senorial.

${ }^{35}$ Véanse, para el contexto general europeo, títulos como S. MENACHE, The vox Dei. Communication in Middle Ages, Oxford, 1990; Paul ZuMTHOR, La medida del mundo, Madrid,

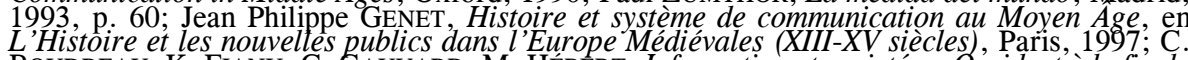
BOUDREAU, K. FIANU, C. GAUVARD, M. HÉBERT, Information et societé en Occident à la fin du Moyen Age, Paris, 2004; Luciano ROSSI et ALII, La circulation de nouvelles au Moyen Age, Alessandria, 2005; o más concretamente para la Corona de Castilla, J.M. NIETO SORIA, Propaganda política y poder real en la Castilla Trastámara. Una perspectiva de análisis, "Anuario de Estudios Medievales", 25/2 (1995), pp. 489-515; Ana Isabel CARRASCO MANCHADO, Discurso político y propaganda en la corte de los Reyes Católicos (1474-1482), Madrid, 2003; Shima OHARA, La propaganda política en torno al conflicto sucesorio de Enrique IV (1457-1474), (tesis doctoral inédita, dirigida por $\mathrm{M}^{\mathrm{a}}$. I. del VAL VALDIVIESO, defendida en la Universidad de Valladolid en 2004). 
de reconocimiento de la autoridad y obtención de recursos de todo tipo. En este sentido, la reciente y tenue presencia del señorío del infante en la villa palentina que hemos observado anteriormente implicaban, por tanto, una mínima disponibilidad de información directa sobre las cuestiones referidas al gobierno del lugar a la altura de 1401, limitada a las nuevas procedentes de sus dos interlocutores afines en Paredes, el alcaide y el recaudador, que sólo participaban de forma restringida en el ámbito de discusión y decisión de los asuntos políticos concejiles. Por tanto, ante problemas como el planteado por el reparto de los oficios municipales, las noticias al respecto, procedentes de las fuentes que eran el propio concejo y los bandos urbanos, podían distar notablemente de ser todo lo abundantes y fiables que para el señor pudieran ser deseables, condicionadas, como estaban, por los intereses particulares de las partes implicadas en el conflicto. Ello suponía una deficiencia en las aptitudes del señor para, por un lado, enjuiciar la situación y, por otro, intervenir en ella de un modo resolutivo. Así, el progresivo aumento del volumen de información manejado sobre el enfrentamiento por la instancia señorial, y el despliegue de mecanismos eficientes para garantizar tanto el aumento en cantidad como en calidad de las noticias disponibles sobre aquél y para implementar actuaciones eficaces en vista a la pacificación y superación del mismo - despacho puntual de los alcaldes García de Cisneros y Gonzalo López, comisión del corregidor Sancho Fernández, fomento de conversaciones entre los bandos, implicación en una vista previa del obispo de Palencia, discusión y acuerdo de la concordia ante la Corte señorial en Medina del Campo- han de ser tenidos en cuenta a la hora de explicar el cambio de iniciativa a lo largo del conflicto hasta quedar en manos del infante don Fernando y el sistema señorial.

Al hilo de lo comentado, el último factor que queríamos subrayar como condicionante de la acción señorial se liga al manejo de una información muy determinante en el entorno del infante respecto a Paredes de Nava: la fama de su oposición a la presencia señorial. Hijo y hermano de rey, heredero del trono hasta el nacimiento de la primera hija de Enrique III a finales de 1401, el infante Fernando se había criado y se movía habitualmente en el ambiente de la Corte real. Su presencia en los círculos cortesanos le habría permitido surtirse de ciertas referencias muy gráficas de la actitud levantisca de Paredes de Nava frente a sus señores, de las cuales hubo necesariamente de estarse al corriente en los mismos. Por una parte, a través del relato del levantamiento que acabó con la vida de Felipe de Castro en 1371, recogido en el ciclo cronístico del canciller Pedro López de Ayala, el cual era elaborado y era objeto de lectura y discusión en este ámbito de la Corte real ${ }^{36}$. Por otra,

${ }^{36}$ Pedro LÓPEZ DE AyAla (ed. y notas de Cayetano Rosell), Crónica de los Reyes de Castilla. Tomo Segundo. Crónica del Rey don Enrique II de Castilla, Madrid, 1953, Año Sexto, 1371 , cap. V, pp 9-10. El consumo de literatura cronística con fines lúdicos y educativos es un hecho común en las cortes bajomedievales europeas (véase para la corte borgoñona en relación con las obras de Froissart, contemporáneas a las de Ayala, Laetitia LE GUAY, Les princes de Bourgogne lecteurs de Froissart. Les rapports entre le text et l'image dans le manuscrits enluminés du livre IV des "Chroniques", Paris, 1998. Sobre la obra cronística del canciller Ayala y su contexto, dentro de una abultada bibliografía: Michel GARCíA, Obra y personalidad del 
mediante el conocimiento de las pretensiones de Paredes de Nava de ligarse al realengo entre 1393 y 1399 que, evidentemente, hubieron de tener eco en la Corte y llegar a oídos del entonces infante heredero ${ }^{37}$. Ciertamente, no era toda y completa la información con que podía contar Fernando de Antequera sobre el lugar que había adquirido y del que iba a tomar posesión en 1401, pero sí al menos una de fama reconocida, capaz de figurar una imagen previa sobre aquella villa que aconsejase prudencia y contemporización al nuevo señor si pretendía asentarse pacíficamente sobre sus nuevos vasallos. Sobre todo, a la hora de dictaminar acerca de la participación en el gobierno urbano en un contexto de pugna entre bandos, lo cual podía afectar muy sensiblemente al reconocimiento de la autoridad señorial si los intereses de alguna de las opiniones en liza se veían lesionados.

\section{MECANISMOS DE ACCIÓN SEÑORIAL ANTE EL CONFLICTO. INFORMACIÓN, NEGOCIACIÓN E IMPOSICIÓN}

Comenzando este punto dedicado a los mecanismos de intervención señorial, pues, las sucesivas ordenanzas sobre la elección de los oficios concejiles, emitidas antes de la Cincuesma, esto es, la fiesta de Pentecostés, de 1401, en julio de 1401 y aún en julio de 1402, se basaron en las peticiones y testimonios presentados por los agentes sociopolíticos locales ante la Corte señorial, sin intervención directa en la villa de oficiales de justicia o pesquisidores del infante que pudiera ser entendida como una forma de mediatización de la autonomía concejil ${ }^{38}$. El objetivo de las mismas era

canciller Ayala, Madrid, 1982; Emilio MITRE FERNÁNDEZ, Tradición e innovación en la obra cronística del Canciller Ayala, "En la España medieval", 19 (1996), pp. 51-76; Germán ORDUNA, El arte narrativo y poético del canciller Ayala, Madrid, 1998.' ÍDEM. Introducción a la obra del Canciller Pero Lopez de Ayala y a la cultura de su tiempo, Álava, 2007. El accesso a las narraciones cronísticas, por otra parte, era un elemento básico dentro de la formación intelectual de la nobleza, particularmente de los varones (I. BECEIRO PITA y Ricardo CóRDOBA DE LA LLAVE, Parentesco, poder y mentalidad. La nobleza castellana, siglos XII-XV, Madrid, 1990 , pp. 109-125; I. BECEIROPITA, Educación y cultura en la nobleza: el reino de Castilla entre los siglos XIII al XV. "Anuario de Estudios Medievales", 21 (1991), pp. 571-590; IDEM, La educación: un derecho y un deber de un cortesano, en J.I. de la IGLESIA DUARTE (coord.), La enseñanza en la Edad Media, "X Semana de Estudios Mediẹvales, Nájẹra 1999”, Logroño, 2000 pp. 175-206), por lo que puede considerarse incluso que el infante hubiera podido acceder a estos conocimientos en un contexto educativo o lúdico cortesano.

${ }^{37}$ Sobre ẹsta cuestión, vinculada a la rivalidad del conde de Noreña y el conde de Trastámara por el dominio de la vilila, véase J.C. MARTín CEA, El mundo rural, cit., pp. 48-53; IDEM, Poderes públicos, cit., pp. 292-293; ÍDEM, Violencia y conflictividad, cit., pp. 129-130; V. MUNOZ GÓMEZ, La adquisición, cit., pp. 122-126; IDEM, La participación política, cit., pp. 284286 y 296-298.

${ }^{38}$ En este sentido, hay considerar como tales, por un lado, las primeras reuniones del concejo sobre el nombramiento de los oficiales en 1401 y las gestiones para lograr que no se realizase "de vando a vando". con la audiencia ante el infante del escribano Alfonso Fernández y su yerno Diego Alfonso Mazón, sobre este negocio en Villalón, donde se ganó carta al respecto, que debieron de ser previas a la visita del señor a Paredes de Nava para ejecutar la toma de posesión de la villa (AMPdN, CP, Borradores, 236/16, f. 62/07 r. y v., 1401; CP 238/03, ff. 02/06 v. y 07 v., 1401). Por otro, al posterior viaje de los representantes del concejo a Medina del Campo, en concreto de Diego Àlfonso Mazón para tratar con el infante y sus alcaldes sobre la concreción definitiva de la nueva normativa sobre elección de oficiales que pretendía obtener el concejo (AMPdN, CP, Borradores, 236/16, f. 62/04 r. 1401; C.P. 238/03, f. 02/09 v., 1401). Y finalmente, con la comparecencia en julio de 1402 de nuevos delegados municipales Juan García 
mantener el status quo entre ambas facciones, de modo que el conjunto de la elite villana viera reconocido su protagonismo político por el poder señorial sin muestras de favoritismo hacia ninguna de las partes que pudieran suponer la animadversión hacia el nuevo señor de quienes se sintieran agraviados. Pero las medidas que pretendían garantizar la concurrencia equitativa de los bandos a los cargos municipales se evidenciaron como infructuosas desde el momento en que fueron sistemáticamente incumplidas por un sector de la elite paredeña, que pretendía asegurarse un control preferente de los nombramientos, discriminando al resto de ella. La evidencia de este fracaso y un mejor conocimiento del contexto político-social de la villa y del problema tras más de un año de peticiones, protestas y declaraciones recibidas conducirían, pues, a la toma de la iniciativa por parte de la autoridad señorial. Ésta se manifestaría en el envío de delegados propios para recabar información y mediar en la disputa entre bandos. Primero, con la comisión de sus alcaldes García de Cisneros y Gonzalo López en julio de 1402 para sondear la situación tras las últimas protestas ${ }^{39}$. Podemos relacionar su misión con un afán de contrastar las versiones mostradas al infante por cada partido sobre el enfrentamiento, presumiblemente parciales, con informaciones tomadas por observadores no vinculados al ámbito local y fieles a los intereses señoriales. La actualización de las informaciones daría lugar, finalmente, a una medida de corte impositivo: el despacho de un corregidor, su vasallo Sancho Fernández, el moço, de Medina del Campo, con plenos poderes para poner fin a los desórdenes ocurridos en la villa por la lucha entre facciones ${ }^{40}$.

El establecimiento de un corregidor por el señor en una de sus villas suponía la introducción de un poderoso elemento de control y fiscalización del aparato concejil, en atención al ejercicio delegado sobre el lugar del mero y mixto imperio y jurisdicción civil y criminal que sobre el mismo detentaba el señor ${ }^{41}$. Esta potestad del corregidor le colocaba en un plano de superioridad en cuanto a funciones judiciales y ejecutivas respecto al concejo, que podía ver vigiladas y mediatizadas todas sus iniciativas por un criado de la Casa del señor, en directa comunicación con éste ${ }^{42}$. El nombramiento de Sancho Fernández, que venía acompañado de la destitución de quienes hasta entonces ostentasen las alcaldías de la villa, por tanto, sólo podía despertar la oposición

Tablares y el procurạdor Juan García Mazón en Medina para ganar del infante una nueva carta sobre los dichos oficiales ante la reacción de los banderizos excluidos (AMPdN, CP, 238/02, f. $01 / 01$ r., s.a. [1401]; 238/03, ff. 02/09 v., $14 \mathrm{v} ., 1401)$. Véase a este respecto la nota $18 \mathrm{y} \mathrm{lo}$ referente a ello en V.' MuÑoz GómEZ, La participación política, cit., pp. 298-300. Aunque los órganos de decisión señorial en torno al infante pudieron haber recurrido al consejo del alcaide de la fortaleza de Paredes o del recaudador para contrastar opiniones que enriqueciesen su conocimiento sobre el problema, no contamos con testimonios al respecto.

${ }^{39} \mathrm{AMPdN}, \mathrm{CP}, 238 / 04$, f. 05 v., 1402: asiento de $60 \mathrm{mrs}$. para dar de cenar a García de Cisneros y Gonzalo López, alcaldes del infante, cuando se presentaron en Paredes.

${ }^{40}$ Véase nota 18 y apéndice documental.

${ }^{41}$ Véase nota 5.

${ }^{42}$ Véase nota 19. Remitimos a nuestro trabajo Administración señorial y gobierno urbano durante los primeros Trastámara. Los corregidores del infante Fernando de Antequera y Leonor de Alburquerque (1392-1421) en "Actas del IV Simposio Internacional de Jóvenes Medievalistas. Lorca 2008 " (en prensa) y a la bibliografía allí citada. 
del concejo, disminuido en sus prerrogativas, y de aquellos que lo controlaban. La negativa del concejo a recibirlo como corregidor y, por tanto, las posteriores quejas ante la Corte señorial, se basaron en principios de interés común a la villa, como era la contradicción de la ley del reino y de los fueros y privilegios municipales por el infante con tal nombramiento y anulación de las alcaldías elegidas por el concejo, además de un implícito rechazo a asumir las cargas fiscales que suponía el oficio del corregidor en salario y posadas para él y sus hombres ${ }^{43}$. Por otra parte, la relación entre el conflicto de bandos y el control del concejo que subyacía al mandato señorial no era, por contra, interesadamente reconocida por los gobernantes municipales. Evidentemente, el infante Fernando desestimó airadamente este desacato a su autoridad, apresando a los representantes del concejo, a todas luces, como rebeldes ${ }^{44}$. Una vez que Sancho Fernández había sido recibido por representantes de ambas facciones, el señor podía contar con ostensible apoyo en Paredes frente a los caballeros del concejo, lo cual nos permite explicar este giro autoritario.

En estas condiciones, el concejo - esto es, los prohombres que pretendían alcanzar una posición hegemónica dentro de él- hubo de deponer su actitud y, del mismo modo que habían hecho sus contarios del bando rival y los propios descontentos de su facción, someterse al dictado señorial. Más importante todavía, todos los agentes sociales paredeños en pugna asumieron los aparatos señoriales de dominación como preferentes para la resolución del enfrentamiento, de buena gana u impelidos por la necesidad. De este modo, no sólo la presencia del corregidor fue reconocida por el concejo, sino que éste recurrió a la mediación de los delegados señoriales en la villa, el corregidor y el alcaide de la fortaleza, y de un importante personaje de la Casa del infante, su camarero Álvaro de Ávila, para la liberación de los emisarios prisioneros $^{45}$. A partir de este punto, desde los distintos niveles de la instancia señorial- Corte, representantes especiales, oficiales locales -se procedería a poner en juego las medidas necesarias para lograr esa equilibrio de poder en el seno del concejo de Paredes del que hablábamos. Éstas, dirigidas a la promoción de un acuerdo entre los bandos a partir del perdón de las afrentas y asesinatos que entre ellos se imputaba, y al mantenimiento del orden público en la villa como contexto ideal para las conversaciones en ausencia de disturbios, culminarían con la citada concordia sellada en la Corte

\footnotetext{
${ }^{43}$ Véase apéndice documental. La respuesta del concejo a Sancho Fernández expone esta línea argumentativa. Hay que recordar que el salario anual de los oficiales concejiles paredeños, en comparación al del corregidor, de $60 \mathrm{mrs}$. diarios, era ridículo: $200 \mathrm{mrs}$. anuales cada uno de los alcaldes, regidores y procurạdores, poco más de medio maravedí (mri.) al día. que para estos 12 oficiales mayores del concejo suponían un total de $2.400 \mathrm{mrs}$. anuales, J.C. MARTíN CEA, El mundo rural, cit., pp. 190, 193 y 196.

${ }^{44}$ Véase nota 21 y apéndice documental.

${ }^{45}$ Véase nota 21.
} 
del infante en Medina del Campo en febrero de 1403 y la consecuente conclusión de la misión del corregidor ${ }^{46}$.

Es en esta última fase del conflicto, el funcionamiento de los distintos engranajes del sistema señorial se manifiesta con una intensidad que, en los momentos anteriores, resultaba mucho más difícil de aprehender. La interacción entre el titular de la jurisdicción - en este caso, el infante Fernando - y el espacio y gentes objeto de la dominación - la villa de Paredes y sus habitantes -, en términos de recopilación y circulación de informaciones, toma de decisiones y ejecución de las mismas, se materializa a partir del despliegue de los múltiples recursos institucionales y humanos atesorados y desarrollados por un aparato complejo, en su doble dimensión, material y administrativa de estado señorial ${ }^{47}$, sociológica de $\operatorname{Casa}^{48}$, liderado por un

${ }^{46}$ Véase nota 23. La presencia de Pedro Fernández Cabeza de Vaca, vasallo del infante y regidor en la cercana villa de Villalón (actual provincia de Valladolid), otro de los centros del estado señorial de Fernando de Antequera y Leonor de Alburquerque (A. M. Villalón, Libro del Acuerdo $\mathrm{n}^{0}$. 1, años 1404-1423, ff. $20 \mathrm{v}-21 \mathrm{v}, 1409-\mathrm{X}-23$, miercoles, donde este personaje aparece consignado como regidor y vasallo del' infante desde, al menos, 1401), junto a sus hombre en Paredes durante siete semanas ha de entenderse, precisamente, como una medida dirigida a evitar los desórdenes entre miembros de ambas facciones, como acción complementaria y necesaria a aquellas dirigidas a promocionar una salida negociada al conflicto (AMPdN, CP, 238/05, f. 04/23 v., 1403).

${ }^{47}$ Véase nota 7.

${ }^{48}$ En un ensayo de conceptualización de los términos para referirse a las estructuras de parentesco y relaciones personales de los colectivos nobiliarios del Antiguo Régimen, linaje, casa y familia, utilizados en las fuentes con carácter polisémico (Ana M ${ }^{\text {a }}$. FRAMIÑ́N SANTAS y Antonio PRESEDO GARAZO, Estructuras de parentesco de la nobleza gallega en 1350-1600: una primera valoración, "Obradoiro de Historia Moderna", 24 [2005], pp. 109-140), se delimitan tres acepciones para el concepto Casa. Por un lado, como espacio físico. En segundo lugar, como conjunto del personal subordinado a un señor. En último término, en su sentido mâs amplio, como abstracción del sustrato material, humano e ideológico del linaje, de un modo casi sinónimo a este concepto (ver pp. 115-121). FRAMIÑ́N SANTAS y PRESEDO GARAZO se hacen eco de las reflexiones de Robin LANE FOX y Anita GUERREAU-JALABERT acerca del problema de carácter heurístico planteado por un uso demasiado laxo y poco preciso de la terminología antropológica y de su adecuación a los objetos históricos estudiados en relación al parentesco nobiliario. Consideramos funcional utilizar la idea de Casa a la hora de referirnos al conjunto de individuos ligados, ya por lazos de parentesco, ya por nexos de patronazgo-servicio, a la estructura olkonómica generada en torno a la familia nobiliaria. Lo traemos a colación simplemente por su uso habitual en las fuentes bajomedievales, si bien somos conscientes de que su carácter genérico y equívoco no ayuda a distinguir las sutiles modalidades de vinculación personal asociadas a los grupos familiares de la nobleza bajomedieval, basadas en fórmulas de parentesco consanguíneo y ficticio, clientelismo, cohabitación y actualización de las formas de relación feudovasallática. Véase, para un acercamiento a estas cuestiones en el ámbito castellano M.C. GERBET, La nobleza en la Corona de Castilla. Sus estructuras sociales en Extremadura (1454-1516), Cáceres, 1989 , pp. 97-118; I. BECEIRO PITA y R. CÓRDOBA DE LA LLAVE, Parentesco, poder en la Corona de Castilla, cit. pp. 35-105 y 331-345; Pablo SÁNCHEZ LEÓN, Nobleza, Estado y clientelas en el feudalismo. En los límites de la Historia Social, en S. CASTILLO (coord.), La Historia Social en España. Actualidad y perspectivas, "Actas del I Congreso de la Asociación de Historia Social. Zaragoza, septiembre, 1990", Madrid, 1991, pp. 197-216; I. BECEIRO PITA, Caballeros y letrados en las casas señoriales zamoranas del $s$. $\dot{X} V$ en "I Congreso de Historia de Zamora. Tomo 3. Medieval y Moderna", Zamora, 1991, pp. 73-86; IDEM, Criados, oficiales y clientelas señoriales en Castilla (siglos XI-XV), "Cuadernos de Historia de España, 75 (1998-1999), pp. 5984; IDEM, Las redes de la oligarquía en los territorios de señorio: las elites de Benavente y su entorno, en El condado de Benavente. Relaciones hispano-portuguesas en la Baja Edad Media. Benavente, 2002, pp. 199-214; Ignacio ALVAREZ BORGE, La nobleza castellana en la Edad Media: familia, patrimonio y poder, en J.I. de la IGLESIA DUARTE, (coord.) La familia en la Edad Media, "XI Semana de Estudios Medievales, Nájera 2000", Logroño, 2001, pp. 221-252; y Pascual MÁTÍNEZ SOPENA, La prosopografía de la nobleza castellano-leonesa (siglos XI-XIII). Balance y perspectivas, "Aragón en la Edad Media. Estudios de Economía y Sociedad", 19 (2006), pp. 119-143. 

pater familias, cabeza de un grupo parentelar nobiliario, como patrón y
señor ${ }^{49}$.

Así, la comitiva de vasallos y clientes del infante provee al aparato señorial del personal necesario para el ejercicio de funciones de muy diversa índole e importancia para los negocios del señor. La organización de este conjunto de personas encuadradas en los sistemas señoriales nobiliarios en época bajomedieval, por otra parte, se articulaba en torno a toda una serie de instituciones con dos dimensiones diferentes no perfectamente separadas. Una doméstica, dedicada al servicio de las necesidades privadas de la familia noble; otra de carácter, si se quiere, más bien "público", enfocada a la gestión de los asuntos relativos al patrimonio señorial. De hecho, ambas se muestra claramente intercomunicadas entre sí. En Castilla, el mejor ejemplo de ello y su principal modelo era, precisamente, la propia Casa del Rey ${ }^{50}$. En el caso del entorno clientelar de Fernando de Antequera y de su esposa, en su calidad de infantes miembros de la familia real, su ordenación respondía de un modo evidente al modelo citado y a esa cierta indiferenciación de funciones que los criados de los infantes podían llegar a desempeñar dependiendo de la situación, de sus aptitudes o de su grado de afinidad y confianza con el señor y su familia.

Como hemos podido observar, los oficiales señoriales en Paredes de Nava procedían de este ámbito. Tanto el corregidor Sancho Fernández como el alcaide de la fortaleza Alfonso Fernández de las Eras eran vasallos del infante, fieles a través del pleito-homenaje a su persona ${ }^{51}$. El protagonismo

\footnotetext{
${ }^{49}$ Véase nota 10.

${ }^{50}$ Particularmente revelador el artículo ya citado de I. BECEIRO PITA, Criados, cit. Respecto a la Casa del Rey de Castilla, con un carácter muy general, M.A. LADERO QUESADA, La Casa Real en la Baja Edad Media,"Historia. Instituciones. Documentos", 25 (1998), pp. 327-356; J. VALDEÓN BARUQUE, La Corte en Castilla en la época Trastámara "Aragón en la Edad Media. Homenaje a la Profesora Carmen Orcástegui Gros", Zaragoza, 1999, pp. 1.597-1.607; o Jaime de SALAZAR Y ACHA, La Casa del Rey de Castilla y León en la Edad Media, Madrid, 2000 . La problemática entre separación o imbricación entre la Corte y los nacientes aparatos del Estaḍo ha quedado subrayada en los estudios dessarrollados en los últimos años sobre esta "sociedad cortesana". A partir de la caracterización cada vez más evidente de la Corte como espacio de representación pero, muy particularmente, como escenario principal del juego político, su diferenciación de los órganos de la administración estatal, en términos de participación y distribución del poder, se antoja particularmente dificultosa. Como reflexión a este respecto, Ronald G. ASCH, Introduction. Court and Household from Fifteenth to Seventeenth Centuries, en R.G. ASCH, y Adolf M. BIRKE, Princes, Patronage and the Nobility. The Court at the Beginning of the Modern Age c. 1450-1650, Oxford, 1991, pp. 1-38. Un buen ejemplo de ello lo encontramos en la Inglaterra bajomedieval (Chris GIVEN-WILSON, The Royal Household and the King's Affinity. Service, Politics and Finance in England 1360-1413, New Haven \& Londres, 1986; D.A.L. MORGAN, The house of policy: the political role of the late Plantagenet household, 1422-1485, en D. STARKEY, ed., The English Court: from the War of the Roses to the Civil War, Londres \& Nueva York, 1987). Una puesta al día en la investigación sobre la Corte en Castilla en $\mathrm{M}^{\mathrm{a}}$. José GARCía VERA, Los estudios sobre la Corte y la sociedad cortesana a fines de la Edad Media. Un balance historiográfico, "Medievalismo", 10 (2000), pp. 207-267.

${ }^{51}$ Sobre el mantenimiento de las fórmulas feudovasalláticas en las formas de prestación de servicio, sobre todo de carácter militar, en la Castilla bajomedieval, véanse, en nota 48, los trabajos citados de I. BECEIRO PITA y P. SÁNCHEZ LEÓN. El nombramiento del corregidor cita explícitamente a Sancho Fernández como "mi vasallo" (ver apéndice documental), término que podemos relacionar con la percepción de un pago en metálico en calidad de tierra por el mantenimiento de un número determinado de lanzas. En cuanto ạl alcaide Alfonso Fernándẹz de las Eras, la tenencia del alcázar de la villa implicaba, por principio jurídico, el establecimiento de una relación de vasallaje en virtud del pleito-homenaje que había de prestarse por la guarda de la fortaleza $\left(\mathrm{M}^{\mathrm{a}}\right.$. Concepción CASTRILLO LlAMAS, Tenencias, alcaides y fortalezas en la
} 
adquirido en los procesos de pacificación del conflicto por los principales oficiales señoriales en la villa, el corregidor Sancho Fernández y, en menor medida, el alcaide de la fortaleza Alfonso Fernández de las Eras, fue notable, al establecer un marco de negociación entre todas las fuerzas sociopolíticas opuestas, concejo y bandos, para la resolución de sus diferencias, fomentando las conversaciones y mediando entre las distintas opiniones hacia un compromis $^{52}$. De hecho, en su calidad de delegado señorial plenipotenciario en Paredes de Nava, no condicionado por los intereses de las facciones en liza - en este sentido, el alcaide podía ser menos fiable, en tanto vecino del lugar-, el corregidor no sólo se convertía en ejecutor de las órdenes señoriales, sino también en observador e informador de primera mano de la evolución de la situación en la villa. Junto con las propias iniciativas emprendidas desde el concejo y los bandos en relación al conflicto ${ }^{53}$, la puesta en conocimiento del infante del origen de las enemistades entre los bandos, del ambiente real de tensión y violencia en la villa, y de los resultados parciales de las primeras fases de negociación por parte del corregidor, a su vez, afectaba directamente a la puesta en práctica por el poder señorial de otras medidas de apoyo a la finalización negociada del conflicto.

En este sentido, podemos individualizar, por una parte, al envío de Pedro Fernández Cabeza de Vaca, regidor de Villalón y vasallo del infante, junto con una tropa durante siete semanas a Paredes de Nava, evidentemente para sostener las gestiones del corregidor, acaso bajo su autoridad, e impedir enfrentamientos cruentos entre los bandos ${ }^{54}$. Por la otra, la propuesta de una vista entre los bandos y el concejo ante un representante especial, uno de los hombres de mayor confianza del infante, el obispo de Palencia, Sancho de Rojas, en su cercana sede episcopal los días 26 y 27 de enero de 1403, acaso con el fin de lograr un acuerdo con el arbitraje del prelado ${ }^{55}$. La documentación que manejamos apenas nos permite conocer que estas intervenciones se produjeron a instancias de la autoridad señorial. Desgraciadamente, no podemos concretar, más allá de ciertas especulaciones, las circunstancias en que se decidió despachar a estos personajes, las órdenes y competencias con

sociedad castellana de la Baja Edad Media. Estado de la investigación y actualización bibliográfica), "Medievalismo", 8 (1998), pp. 153-199, en particular pp. 167-172.

${ }^{52}$ Así lo denota la participación del corregidor en las conversaciones relativas al perdón y concordia entre los bandos, desde su inicio hasta la definitiva firma del acuerdo en Medina, última fase de las discusiones de avenencia. Ver notas 20-23. En cuanto al alcaide, también actuó activamente en estas negociaciones, particularmente en el acuerdo alcanzado en Medina, siendo reconocido por el concejo "... por que tomase cargo de librar conel dicho sennor infante enlo que conpliese al conceio ... en su labor mediadora con la entrega de una mula que costó 1.200 mrs. (AMPdN, CP, 238/01, f. 90/06 v., s.a. [1402]).

${ }^{53}$ Hay que recordar que, al menos en una ocasión, los oficiales concejiles enviaron una embajada al infante a Medina del Campo en relación con la avenencia de bandos, formada por Pedro García hijo de Juan Alfonso, y por Domingo Fernández Galeano con Rodrigo Alvarez de la Serna (AMPdN, CP, 238/05, f.' 04/08 v., 1403). Por otro lado, sabemos de otros gastos realizados por el procurador Pedro García y por el corregidor a cuenta del concejo para gestionar esta posible concordia con el infante (AMPdN, CP, 238/05, ff. 04/19 r., 20 r., 23 v.).

${ }^{54}$ Véase nota 46.

${ }^{55}$ AMPdN, CP, Borradores, 236/18, ff. 64/10 r.-13 v., 19 r.-23 v., 1403; CP, 238/05, ff. 04/19 r., 22 r., 29 r. -39 r., 1403. 
que fueron destinados en sus misiones, los flujos de comunicación desarrollados por estos hombres con las esferas señoriales, de decisión de la Corte y de jurisdicción municipal, y con los agentes sociopolíticos concejiles.

Ahora bien, la elección de los servidores señoriales a quienes se encomiendan este tipo de intervenciones puntuales de la esfera señorial en un asunto de rango local, en la línea de la visita realizada a Paredes por los alcaldes del infante García de Cisneros y Gonzalo López en julio de 1402 tras las últimas protestas por la elección del concejo ese año, como podemos observar en estos tres casos, obedece a condiciones distintas. En el de los alcaldes, por su condición de oficiales de justicia en la Corte señorial. Esto es, por su experiencia en asuntos jurídicos y su proximidad a la persona del infante en el desempeño de sus funciones judiciales ${ }^{56}$. En el de Pedro Fernández Cabeza de Vaca, como criado de una cierta confianza, ducho en asuntos de armas, a causa de la proximidad geográfica entre Villalón y Paredes, que le capacitaba para reunir y sostener los recursos militares necesarios para su misión rápida y eficazmente ${ }^{57}$. Finalmente, en el de Sancho de Rojas se basaría especialmente en la intimidad de la relación entre el infante y este clérigo, que había ya participado en las negociaciones de paz entre Castilla y Portugal en 1399. A partir de su presencia en la Corte de Enrique III, Sancho de Rojas pasaría a convertirse en uno de los hombres de confianza de su hermano, actuando a su servicio en asuntos de máxima relevancia como las negociaciones con los reyes de Navarra para el matrimonio entre la infanta de Navarra, doña Isabel, y el segundogénito de Fernando de Antequera, don Juan, en $1403^{58}$, o la concesión de diversas mercedes al mariscal García González de Herrera en $1404^{59}$. No obstante, desconocemos si entre 1402-1403 ostentaba algún oficio específico dentro de la Casa del infante o si percibía de la Hacienda señorial algún tipo de mantenimiento, merced o quitación, como signos formales de una relación clientelar ${ }^{60}$. Además de ello, habría que considerar el peso de su formación jurídica, obtenida como estudiante de Derecho Canónico en Salamanca, y su condición

\footnotetext{
${ }^{56}$ La administración judicial señorial, encabezada por el propio señor en su Corte, contaba con una serie de alcaldes, cuya función principal era el ejercicio de la justicia en este espacio cortesano, por asimilación al modelo que en este sentido habían supuesto los alcaldes de Corte de la Casa Real, documentados al menos desde época de Alfonso X y luego integrados en la Audiencia y Chancillería (David TORRES SANZ, La administración central castellana en la Baja Edad Media, Valladolid, 1982, pp. 126-134). Podemos ver, no obstante, que como personas con conocimientos en el ejercicio del Derecho, podían ser comisionados en otras misiones fuera de la propia Corte.

${ }^{57}$ Ver nota 46. Las aptitudẹ militares de Pedro Fernández Cabeza de Vaca, vecino de Villalón, y el valor de sus servicios se verían demostrados y recompensados con su ascenso en la Casa de Fernando de Antequera al oficio doméstico de carácter castrense de alférez del infante

(A. M. Villalón, Libro del Acuerdo no. 1, años 1404-1423, ff. 9 v.-10 r., 1409-VII-4, jueves).

${ }^{58}$ Archivo General de Navarra, Comptos, caja. 90, no 14.

${ }^{59}$ Archivo General de Simancas, Patronato Real, legajo 58, f. 30.

${ }^{60}$ Las referencias documentales que ligan a Sancho de Rojas y al infante Fernando antes de 1404 se limitan a los ejemplos expuestos anteriormente. En ninguno de ellos se cita para el obispo de Palencia ningún oficio dentro del sistema señorial o es nombrado como "vasallo", "criado" u otra denominación que denote una relación patrón-cliente. La pérdida de cualquiér registro hacendístico del infante impiden conocer si podía figurar en sus listas de pago.
} 
de oidor de la Real Audiencia, la cercanía de Paredes de Nava a la sede palentina, y la pertenencia de esta villa a la diócesis del obispo don Sancho, lo cual redundaba en su autoridad para mediar en las disputas entre quienes se hallaban bajo su autoridad pastoral y, como tal, podían reconocerlo como árbitro competente ${ }^{61}$. Podemos observar que factores como la formación y las aptitudes personales, la disponibilidad temporal y espacial pero, sobre todo, la intensidad de los lazos de afinidad entre cliente y señor, eran determinantes a la hora de definir la participación de la estructura clientelar en los asuntos que afectaban a la administración del estado señorial. Es decir, a su integración diferenciada en los aparatos señoriales, más allá de las funciones concretas correspondientes al oficio que pudieran ostentar estos individuos dentro de la Casa. En este sentido, el ejercicio de cometidos excepcionales como los observados por clientes de especial aptitud, en un nivel intermedio entre las esferas local y superior del poder señorial, intercomunicándolas y reforzando la implantación práctica de su autoridad sobre los vasallos sujetos a dominio, evidencia la capacidad de adaptación de las instituciones con que contaban los sistemas señoriales de la época ante los problemas que habían de gestionar. Laxamente estructuradas, la propia intercomunicación, o incluso indefinición, de sus ámbitos competenciales les dotaba de una cierta operatividad que podía compensar ciertas carencias, como la escasa implantación en un espacio concejil, limitándonos al caso que nos ocupa.

De cualquier modo, todos los niveles del aparato señorial terminaban remitiendo a su centro de liderazgo y de toma de decisiones. Esto es, al propio señor, en tanto patrón de sus clientes y vasallos y depositario de la autoridad jurisdiccional sobre sus dominados. Conviene señalar que, pese a que la administración de sus estados y sus intereses políticos solía condicionar para los nobles un habitual modo de vida itinerante ${ }^{62}$, entre 1401 y 1403 , durante la mayor parte del tiempo en que se desarrolló el conflicto, el infante Fernando y su comitiva se asentaron en Medina del Campo. De hecho, esta villa fue la sede preferida de Fernando de Antequera y su familia en Castilla y se convirtió en el núcleo capitalino de su estado señorial, como centro de residencia y gestión del poder relativamente permanente del conjunto de individuos e instituciones -oficios domésticos, cancillería, tribunal de justicia, tesorería y contaduría, fundamentalmente- que conformaban en

\footnotetext{
${ }^{61}$ Desgraciadamente, la trayectoria de Sancho de Rojas no ha sido objeto de estudio monográfico pese a su espectacular ascenso político, a la sombra de Fernando de Antequera, hasta convertirse en canciller mayor de Juan II de Castilla, canciller del Sello de la Poridad del infante, arzobispo de Toledo y finalmente en el hombre fuerte de la Corte castellana tras la muerte de su patrón. Para un acercamiento a este personaje, I. BECEIRO PITA, Las negociaciones entre Castilla y Portugal en 1399, "Revista da Faculdade de Letras", II Série, XIII (1996), pp. 149-185, en concreto, 180-184; y Oscar VILLARROEL GONZÁLEZ, Las relaciones entre la monarquía y el arzobispado de Toledo en época de Juan II de Castilla (1406-1454), Toledo, 2002, pp. 16-20.

${ }^{62}$ En este sentido, el paralelismo con la Corte real es evidente. Sobre el al propio carácter nómada de ésta, véanse los trabajos de GARCÍA VERA, LADERO QUESADA, SALAZAR Y ACHA y VALDEÓN BARUQUE en la nota 50. Como ejemplo de estos comportamientos en el caso que estamos analizando, el viaje del infante por sus villas de Tierra de Campos en 1401, durante el cual tuvo lugar la primera petición respecto a los oficios concejiles de Paredes de Nava, estando en Villalón, y la posterior toma de posesión de Paredes de Nava (ver notas 16 y 17).
} 
torno al infante su Corte señorial ${ }^{63}$. Dentro de una mayor complejidad que la documentación referente al conflicto paredeño no nos permite aprehender, la instancia superior señorial se manifiesta en relación al mismo en dos sentidos diferenciados que procede distinguir.

Por una parte, la Corte señorial se muestra fundamentalmente como un espacio de toma de decisiones, ya sea a partir de los requerimientos elevados ante ella, con la promulgación de ordenanzas por ejemplo, o de motu propio, a razón de las informaciones recopiladas, con la comisión de un corregidor o la promoción de negociaciones entre los bandos enfrentados para alcanzar una composición entre ellos. No obstante, conviene subrayar que los procesos de decisión, aunque dependían en último término de la voluntad del infante, se veían afectados por la participación en ellos de ciertos individuos que, por su proximidad física al señor dentro del espacio cortesano y por su afinidad hacia éste en términos de servicio y confianza, podían aconsejar sobre ciertas cuestiones o hacer valer su opinión al respecto como apreciable y acertada. En este sentido, tenemos constancia del concurso en esos procesos de un grupo relativamente reducido y selecto de oficiales y clientes insertos en el círculo más íntimo de la Casa del infante gracias al reconocimiento que el concejo de Paredes hizo de la intercesión realizada en su favor ante el infante por algunos de ellos. Es el caso de Álvaro de Ávila, camarero del infante y uno de sus más fieles criados, que intervino decisivamente en la liberación de los mensajeros apresados y tomó cargo por el concejo para promover ante su señor la resolución del conflicto ${ }^{64}$, o el de Pedro García, escribano de cámara del infante Fernando y, por tanto, de inmediato acceso a su persona para el despacho de todo tipo de negocios ${ }^{65}$. Junto con ellos, el propio obispo de Sancho de Rojas podría ser señalado como otra de esas

\footnotetext{
${ }^{63}$ Así se deduce del despacho de asuntos judiciales y hacendísticos por parte de sus vasallos en Medina del Campo - tomense como ejemplo las anotaciones recogidas en la contabilidad paredeña entre 1401 y 1410 (AMPdN, CP, 328/02 [1401] a 238/12 [1410]), pero también de distintas iniciativas del infante que supusieron una particular dignificación de la villa, tales como la remodelación de los palacios reales en Medina por el infante, la fundación de varios conventos o el establecimiento de las famosas ferias (Antonio SÁNCHEZ DEL BARRIO, Historia y evolución urbanística de una villa ferial y mercantil. Medina del Campo entre los siglos XV y XVI (tesis doctoral inédita, dirigida por $\mathbf{M}^{\mathrm{a}}$. I. del VAL VALDIVIESO, defendida en la Universidad de Valladolid, 2005).

${ }^{64} \mathrm{AMPdN}$, CP, 238/01, f. 90/06 v., s.a. [1402]: asiento de 2.000 mrs. que costó una mula que el concejo le envió en reconocimiento de su mediación. Álvaro de Ávila alcanzaría una notable proyección al servicio de Fernando de Antequera, convirtiéndose en su mariscal y siendo objeto de diferentes mercedes, además de casar con la hija del almirante de Francia, Robin de Bracamonte (Alfonso FRANCO SILVA, El mariscal Alvaro de Avila y los orígenes del condado de Peñaranda, en La fortuna y el poder. Estudios sobre las bases económicas de la aristocracia castellana (s. XIV-XV), Cádiz, 1996, pp. 241-264).

${ }^{65} \mathrm{AMPdN}$, CP, 238/05, f. 04/23 v., 1403: asiento de $2.000 \mathrm{mrs}$. que costó una mula que se le regaló y envió a Medina con Alfonso García Tomás, uno de los prohombres de Paredes. Pedro Garcia aparece consignado como "escriuano del dicho sennor infante", encargado de la escrituración y de la fe pública de la mayor parte de los documentos expedidos por la cancillería del infante entre 1400 y 1406 . La continuidad en el ejercicio de esas funciones señala a su ejercicio como tal escribano de cámara personal del infante Fernando. Véase, a modo de ejemplo, la documentación conservada en Cuéllar, otra de las villas señoreadas por Fernando de Antequera (Antonio UBIETO ARTETA (ed.), Colección diplomática de Cuéllar, Segovia, 1961, doc. 156-179, pp. 315-402; Archivo Histórico Municipal de Cuéllar. Archivo de la Comunidad de Villa y Tierra. Sección Ia (XIV-3), docs. 10, 12-14, 16, 18), o la merced al mariscal García González de Herrera (véase nota 59).
} 
personas capacitadas para ejercer influencia en las decisiones del infante, si bien no contamos con evidencias expresas de ello en relación con su ejercicio en las vistas entre los bandos en su sede de Palencia.

Por otra parte, el ámbito de la Corte señorial se manifiesta, en su faceta de escenario de acción política, como un espacio ideal para la negociación. De hecho, ya fuera por el fracaso de la reunión entablada en Palencia los días 26 y 27 de enero de 1403 entre don Fernando, hijo del conde Noreña, y sus contrarios para alcanzar una avenencia, ya porque estas conversaciones tuvieran un carácter exclusivamente preliminar, lo cierto es que las últimas reuniones entre los bandos y el concejo y la firma de la concordia entre ellos tuvieron lugar en Medina del Campo ${ }^{66}$. Sin embargo, el acceso al entorno de la Corte del infante, en última instancia al propio señor y sus oficiales, por parte de las facciones enfrentadas no se corresponde precisamente con una dirección expresa del proceso negociador por parte del infante Fernando. Las discusiones entre don Fernando, hijo del conde de Noreña, y seis representantes electos de sus agraviados se extendieron entre los días 1 y 9 de febrero fundamentalmente, con la presencia del escribano Alfonso Fernández y el procurador Pedro García, como representantes del concejo, y la intermediación del corregidor Sancho Fernández y el alcaide Alfonso Fernández de las Eras ${ }^{67}$. Es importante señalar, precisamente, que estas conversaciones se desarrollaron en Medina, pero no en las estancias palaciegas de la Corte señorial, y que en ellas no participó el infante ni ninguno de los hombres de su Casa. De hecho, la única comparecencia ante Fernando de Antequera de las facciones paredeñas tuvo lugar el viernes 9 de febrero, tras lo cual, al día siguiente, la mayor parte de los comisionados volvió a Paredes ${ }^{68}$. De ello se deduce que ese día hubo de producirse una audiencia ante el infante en que los bandos sellarían el acuerdo por el que sus disputas quedaban saldadas ${ }^{69}$. Así, el peso de las negociaciones y los principios sobre los que debía alcanzarse la avenencia recaerían sobre los propios actores locales enfrentados, mientras que la intervención del mismo señor en este punto sería mínima, limitada a la posición moderadora que su

${ }^{66} \mathrm{AMPdN}, \mathrm{CP}, 238 / 05$, ff. 29 r.-39 r., 1403. Entre las anotaciones contables relativas a los gastos desprendidos en los viajes y reuniones que desembocaron en la concordia de Medina (ver nota 22), destaca la existencia de un cuaderno en que sọn compilados en un único bloque todos los desembolsos realizados desde el primer desplazamiento a Palencia hasta el retorno de los últimos delegados a Paredes de Nava desde Medina del Campo. Ello hace pensar que, al menos desde la óptica concejil, el conjunto de estas conversaciones formaban un único bloque.

${ }^{67} \mathrm{Ibidem}$. Estos oficiales señoriales acudieron con sus hombres a Medina, plausiblemente para garantizar la seguridad de las partes convocadas frente a posibles violencias durante las conversaciones entre ellas.

${ }^{68}$ Ibidem. El viernes 9 de febrero se consignan los pagos realizados a los porteros del infante, un dispendio de carácter protocolario que se relaciona con la celebración de una audiencia ante su persona. En otro orden de cosas, el procurador Pedro García y otros hombres, además del corregidor, permanecieron en Medina hasta el día 11, llegando a Paredes el día 14 de febrero, para tratar otros asuntos no relativos al enfrentamiento entre los bandos.

${ }^{69}$ Ibidem. El viernes 9 de febrero se consignan los pagos realizados a los porteros del infante, 50 y 30 mrs. respectivamente. 
corregidor y su alcaide pudieran ejercer y a la presidencia del acto formal de pacificación de los bandos ${ }^{70}$.

En cualquier caso, la Corte parece ofrecer unas condiciones particularmente aptas para la negociación y la resolución de conflictos para los vasallos sujetos a la autoridad señorial allí asentada. El marco cortesano, incluso sus aledaños, en este caso el interior de la villa de Medina, a resultas de las garantías de seguridad ofrecidas por el imperio de la jurisdicción señorial a las personas y las causas de sus vasallos, se constituye en un campo neutral para los dominados que acuden a él, propicio para la conversación entre bandos antagónicos. En la teoría jurídica de la época subyacen, de hecho, los principios que auspiciaban la ausencia de violencia en este espacio. Ésta consagraba la inmunidad de quienes concurrían a la Corte del Rey por toda suerte de motivos, particularmente cuestiones de justicia, sobre la base de la honra a la persona del Rey y el respeto a su autoridad como guardián y defensor del Reino ${ }^{71}$. Si entendemos la esfera de poder señorial como partícipe, por delegación y por asimilación, de las potestades y de las fórmulas del poder monárquico, la letra de la ley se adapta sin gran dificultad al ámbito de las cortes señoriales, más aún si cabe a la de un infante miembro de la familia real. Sea como fuere, estas concreciones normativas nos remiten al requisito de seguro, de observancia de la paz y protección física legal de las personas y sus posesiones, necesario en un lugar que se define particularmente como espacio de acción política y de gestión del poder ${ }^{72}$. Entonces, la práctica de la negociación encuentra en la Corte una escena propicia toda vez

${ }^{70}$ Desconocemos si el corregidor o el alcaide pudieron ser llamados a su presencia por el infante Fernando, al no quedar recogida mención a estas posibles audiencias por no suponer gasto a cuenta del concejo.

${ }^{71}$ Tanto las Partidas, expresamente (Gregorio LóPEz (ed.), Las Siete Partidas del Sabio Rey Don Alfonso el IX, Barcelona, 1843, Partida II, Título XVI, Leyes 2-4, pp. 801-805), como é Ordenamiento de Alcalá de 1348, de un modo tangencial (Ignacio JORDÁN DE ASSO Y DEL RÍO, y Miguel de MANUEL RoDRÍGUEZ (ed.), El Ordenamiento de Leyes que D. Alfonso XI hizo en las Cortes de Alcalá de Henares el año de Mil Trescientos y Cuarente y Ocho, Madrid, 1847, Título XX, Ley III, pp. 30-31), reconocen este principio. Los espacios delimitados por este seguro no sólo se limitaban a los propios palacios reales sino que incluían la villa o lugar en que el Rey posase, sus alrededores y los caminos recorridos durante los viajes de ida y vuelta de la Corte por las personas que se acercaran a ella.

${ }^{72}$ Junto a unas funciones residenciales y administrativas, se puede apuntar un importante componente político en las cortes señoriales en el Occidente medieval europeo. Como tales, este tipo de centros podían convertirse en foros preferentes para la negociación y promoción de los intereses de las aristocracias y demás elites políticas de los territorios dominados por el señor y aún de aquellos otros circundantes y afectados por su influencia. La articulación de algunas curias señoriales plenomedievales permite inferir lo incipiente de estas características en los siglos XIIXIII (Jean-Francois NIEUS, Un pouvoir comtal entre Flandre et France. Saint-Pol, 1000-1300, Bruxelles, 2005, pp. 357-423), si bien es al final de la Edad Media cuando se observa la maduración de las mismas. Así puede sugerirse a partir de la participación en oficios ydignidades de la corte de René de Anjou, conde de Anjou y Provenza y destronado rey de Nápoles por Alfonso V de Aragón, de nobles y letrados procedentes de sus dispersos dominios franceses, provenzales e italianos entre 1434 y 1480 (Martin AURELL, Jean-Paul BOYER, Noël COULET, La Provence au Moyen Age, Aix-en-Provence, 2005, pp. 321-324), o de las estrategias emprendidas por los Thüngen, linaje de caballeros de Franconia, en relación con el servicio a los principales príncipes de la región y que, a partir de mediados del siglo XV, se centrarán en el afianzamiento de la familia en el entorno del más importante de éstos, el obispo de Wurtzburg (Joseph MORSEL, La noblesse contre le prince. L'espace social des Thüngen à la fin du Moyen Âge (Franconie, v. 1250-1525), Stuttgart, 2000, pp. 139-282, muy en particular pp. 232-272). 
que las partes reunidas se someten a la jurisdicción detentada por el señor ${ }^{73}$. Esta posición de superioridad señorial es la que aporta otro importante requisito para la conclusión de los enfrentamientos elevados hasta la Corte, tanto en el ejercicio de sus facultades judiciales para aplicar una sentencia como mediante la puesta en juego de una especial capacidad de arbitraje y mediación entre las partes.

\section{BALANCE DE FUERZAS ENTRE LOS PODERES LOCALES Y EL SISTEMA SEÑORIAL TRAS LA CONCORDIA DE 1403}

Que el concejo de Paredes de Nava reconociese el final del oficio del corregidor Sancho Fernández con un regalo de 2.000 mrs. "... por el vien que fizo aesta villa por la poner en paz..."74 resulta bastante significativo a la hora de calibrar la satisfacción de las elites locales respecto a los términos de la avenencia alcanzada y a la propia intermediación del aparato señorial en la consecución de la misma. Desconocemos los asuntos que fueron objeto de concertación en este acuerdo pero todo parece indicar que, además de ajustar los perdones y satisfacciones entre los bandos por los asesinatos y otros males cometidos, se debió de llegar a un arreglo relativo a la elección de los oficios concejiles, razón última de las disputas. Pese a la imposibilidad de datar el documento referido en el inventario de 1820 del archivo municipal de Paredes en que se cita una ordenanza concerniente a un nuevo procedimiento de nombramiento de cargos municipales - la cual, previo acuerdo de todas las partes involucradas, excluía de los oficios a las personas integradas en facciones -, sí existe un elemento circunstancial que permite relacionarla de algún modo con la concordia firmada en Medina del Campo en febrero de 1403. Nos referimos al momento de elección de los mismos, que en esa regulación se fijaba el día de Año Nuevo o su víspera ${ }^{75}$. Si la renovación de

\footnotetext{
${ }^{73}$ Seguridad y negociación son dos conceptos inseparables dentro de la cultura política medieval, observables en toda suerte de contextos conflictivos. Así ocurre en el caso local que estamos observando pero también en otros cuya profundidad puede afectar al conjunto de una entidad política mucho mayor y que, por su complejidad, exigen el despliegue de soluciones de excepción. En este nivel, el llamado Seguro de Tordesillas de 1439 resulta un espléndido banco de pruebas en la Castilla bajomedieval para el análisis los aspectos que citábamos, tal y como evidencian los trabajos de Fernando GÓMEZ REDONDO, Elocución y diplomacia: rivalidades culturales en Tordesillas; $\mathrm{M}^{\mathrm{a}}$. Pilar RÁBADE OBRADÓ, Confederaciones, seguros y pleitos homenajes: el contexto documental del "Seguro de Tordesillas"; y, muy especialmente, A.I. CARRASCO MANCHADO, Léxico político en el "Seguro de Tordesillas": conflicto, pactos y autoridad real, en François FORONDA y A.I. CARRASCO MANCHADO (dirs.), Du conträt d'alliance au contrat politique. Cultures et sociétés politiques dans la péninsule Ibérique à la fin du Moyen Age, Toulouse, 2007, pp. 49-64, 65-84 y 85-137, respectivamente.

${ }^{74}$ Véase nota 23.

${ }^{75}$ Se trata de la descripción de una petición sin data presentada por el concejo al entonces señor de la villa, no declarado, hoy desaparecida. Por ella, solicitaban que revocase cierto ordenamiento que habían hecho, y el señor había aprobado, sobre la elección de los oficios municipales. Esta se realizaría “....el día de año nuevo, o su Víspera...”, seleccionando los oficiales salientes “...de cuatro Personas de cada Varrio, que fueren idóneas, y non aderidas a partịdo alguno, las cuales Juntas, así nombradas, hechasen suertes para ver a quién tocaba ser Regidores, y oficiales, y en quienes recayesen, que hubiese dicho Oficio..." por un año. El motivo para requerir su derogación era que, si la ordenanza “...la habían hecho para que no se hiciese la elección en Persona de Vando; y que si antes de hacer la ordenanza esperimentaban
} 
los oficiales concejiles se había producido tradicionalmente en Paredes de Nava por Pentecostés, y, en efecto, la estructura de los cuadernos contables refleja este hecho, a partir de 1403 hallamos un cambio plasmado en estos mismos documentos ${ }^{76}$. Ese año, los procuradores comenzaron su oficio a principios del año, en concreto el 2 de febrero, y no por la Cincuesma, como era costumbre hasta entonces ${ }^{77}$, y desde 1404 los procuradores comenzaron el 1 de enero ${ }^{78}$. Lógicamente, lo propio ocurriría con el resto de oficios electos, alcaldes y regidores fundamentalmente. En consecuencia, no resulta descabellado asociar la ordenanza confeccionada por el concejo y luego refrendada por el señor señalada en el inventario de 1820 con las conversaciones establecidas entre las distintas fuerzas locales desde la llegada del corregidor a la villa hasta la audiencia ante el infante en Medina del Campo en que se formalizó la concordia entre los bandos. Incluso se antoja viable, sin olvidar todas las reservas a que obligan las imprecisiones formales de este testimonio, asociar este último acto con la ratificación del reglamento sobre los oficios municipales por el infante Fernando.

De un modo u otro, lo que sí es cierto es que, durante los restantes años del señorío de Fernando de Antequera sobre Paredes de Nava, hasta su muerte en abril de 1416, las referencias a vandos en la documentación municipal desaparecen completamente, lo cual denota que no hubo rebrotes del enfrentamiento abierto entre las facciones de la elite local dominante. No obstante, durante esos años hemos podido localizar toda una serie de iniciativas que señalan hacia un esfuerzo preciso de la autoridad señorial por mantener el orden público en la villa, acaso relacionado con una pervivencia latente de la hostilidad entre facciones. Destacan, en primer lugar, las referencias a la presencia de tres corregidores sucesivos entre 1407 y 1408: Fernán Alfonso, Gómez Arias y Juan Fernández del Moral, quien a su vez era

algún daño, o división, al presente esperimentaban aun más, sin embargo de que prestaban Juramento, pues podía llegar el caso de no hallar Personas que no fuesen de partido, y esto hera en perjuicio de sus Conciencias" (AMPdN, 10026/03. Inventario General del Archivo. 1820, f. 51 r. y v. Doc. 162).

${ }^{76} \mathrm{AMPdN}, \mathrm{CP}$, Borradores, 236/15, f. 61/03, 1400; CP, 238/03, f. 02/04 r., 1401-1402: anotaciones correspondientes a los procuradores de los años 1400 y 1401 , para los cuales se refiere el inicio de sus oficios en la Cincuesma dẹl año correspondiente "fasta un anno conplido siguiente", que se entiende hasta la Cincuesma siguiente.

${ }^{77} \mathrm{AMPdN}, \mathrm{CP}, 238 / 04$, f. 03/01 r., 1402: inicio de las cuentas del procurador Fernán García Cabras, cuyo oficio duró de la Cincuesma de 1402 "fasta fin de anno de CCCC nombraron otros procuradores". La referencia de la duración del oficio hasta final de 1403 es, probablemente, un error inconsciente del escribano cuando habría de haber escrito 1402, ya que sabemos a ciencia cierta que en febrero de 1403 se pusieron nuevos procuradores (ver nota siguiente).

${ }^{78} \mathrm{AMPdN}, \mathrm{CP}, 238 / 05$, f. 04/01 r., 1403: inịcio de la cuenta de procuración de Alfonso García Moriscote, procurador con Pedro García, hijo de Toribio Fernández Alfayate, desde 2-II1403 hasta fin de ese ano; 238/06, f. 05/03 r. 1404: cuenta de los procuradores Juan Martínez Harnueco y Pedro González Chaperete, que lo fueron desde 1-I-1404 hasta un año cumplido: 238/07, f. 06/02 r , 1405; 238/08, f. 07/02 r., 1406: inicios de cuentas de los procuradores de 1405 y 1406 , en las que, si bien no se cita el día de inicio de su oficio, la revisión de sus respectivas contabilidades por el concejo a en febrero y marzo de los años siguientes da a entender el comienzo de sus responsabilidades en enero. 
regidor en Villalón ${ }^{79}$. Desconocemos qué circunstancias motivaron sus nombramientos pero sí sabemos que, tras una presencia efímera de los dos primeros, el corregimiento de Juan Fernández desató en Paredes de Nava un profundo descontento que desembocó en un tumultuoso proceso contra él ${ }^{80}$. La posible pretensión del infante de normalizar la presencia del corregidor en la villa como su representante permanente en el concejo y supervisor del mismo a partir del argumento de la reincidencia de los conflictos internos resultó radicalmente atajada por la oposición unificada hacia ella del grupo dirigente local. En los años posteriores, Fernando de Antequera se abstendría de intentar repetir esta fórmula de penetración en el ámbito local, asumiendo que la gestión municipal quedase, sin mayores cortapisas, en manos de los prohombres de la villa con tal que el concejo cumpliera con los requerimientos fiscales y militares a que fuera sometido. En cualquier caso, ello no fue óbice para que la autoridad señorial insistiera en la defensa de la paz pública con la expedición, ya en segundo lugar, de ordenanzas que prohibían que ningún vecino de la villa portase armas salvo los oficiales de justicia del concejo, primeramente con motivo de la visita del infante a Paredes en agosto de $1409^{81}$, posteriormente en 1415 , ante el incumplimiento de las anteriores órdenes en esta línea, “...por que meior e más en paz byuiésedes ..." 82 .

${ }^{79}$ Juan Fernández del Moral era regidor en Villalón desde al menos 1401, como se desprende del traslado de una carta del infante dada a 25 de julio de ese año en que ya figura como tal y nombrado por don Fernando como el resto de sus otros cinco colegas (A. M. Viflalón, Libro del Acuerdo $\mathrm{n}^{\mathrm{g}}$. 1, años 1404-1423, ff. 20 v.-21 v., 1409-X-23, miércoles).

${ }^{80}$ Apenas sabemos nada de los dos primeros corregidores salvo su presencia. En cuanto a Juan Fernández del Moral, tenemos constancia de que, nombrado por un período de 3 meses, se negó a abandonar su oficiọ hasta que recibió orden expresa del infante para ello ante las protestas del concejo. Las acusaciones contra él tocaban también a un uso abusivo de la autoridad contra la población y a sus frecuentes ausencias de la villa, que suponían una mengua de justicia, pues obligaban a los vecinos a trasladarse a Villalón o a Castromocho (actual provincia de Palencia) para despachar con él los asuntos pertinentes. El proceso que la villa trató de mover contra él pasó por múltiples penalidades al negarse Juan Fernández a aceptar los emplazamientos que los paredeños le hicieron, aún inçumpliendo las cartas ganadas por éstos ante el infante y el propio rey en Turégano (actual provincia de Segovia). Esta contumąz desobediencia condujo a que los de Paredes acudieran a Valladolid al infante a solicitar permiso para prender a Juan Fernandez, tras lo cual se dirigieron a Villalón con hombres armados para apresarlo, cosa que no consiguieron al haber éste escapado. Las noticias sobre este litigio se interrumpen en este punto, por lo que desconocemos cómo terminó de librarse este negocio. Véase al respecto de estos tres corregimientos: AMPdN, CP, 238/09, ff. 08/14 r., 30v., 1407; C.P. Borradores, 236/22, ff. 68/20 r.-23-v., 1408; J. 'C. MARTÍN CEA, El mundo rural, cit., pp. 51 y 183; IDEM, Poderes públicos, cit., pp. 283, nota 66, y pp. 292-293.

${ }^{81} \mathrm{AMPdN}, \mathrm{CP}, 238 / 11$, f. 10/11 y., 1409: pago de $50 \mathrm{mrs}$. al trompeta del infante porque llevó la trompeta en el pregôn que se hizo en la villa del bando del infante de "...que ninguno non fuese osado de traer armas".

${ }^{82}$ AMPdN (AHP, Palencia), Varios, Caja 65, $\mathrm{n}^{\mathrm{o}}$. 3, 1415-III-12, Valladolid. La cita textual remite al motivo por el que el infante Fernando estableció esta prohibición en varias ocasiones, no sólo en 1409, con anterioridad a su ascenso al trono de la Corona de Aragón en 1412. Este ordenanza reiterativa, por otra parte, fue despachada por el obispo de Palencia, Sancho de Rojas, en nombre del rey de Aragón y con su sello, quien, deșde que Fernando de Antequera entró en los estados de la Corona de Aragón, se había convertido en el administrador de sus dominios señoriales castellanos, como queda evidenciado a partir de la ordenación de las cuantías de los pedidos o de ordenanzas municipales en villas como Paredes de Nava o Alba de Tormes (AMPdN, CP, 239/01-05, 1412-1416; AM de Alba de Tormes, Libros de Actas del Concejo, 1413 y 1416; J. Ma MONSALVO ANTÓN, Documentación Histórica del Archivo Municipal de Alba de Tormes (siglo XV), Salamanca, 1988, pp. 62-82).

En otro orden de cosas, en el momento en que fue realizada la consulta de este documento, en noviembre de 2006, esta caja, junto con otras más procedentes del Archivo Municipal de Paredes de Nava, permanecía depositadas en el Archivo Histórico Provincial de Palencia, donde 
La necesidad reiterada de limitar posibles acciones violentas, particularmente protagonizadas por ballesteros y escuderos de la villa citados expresamente en la ordenanza -, nos coloca ante una situación en que el orden interno en la población que la autoridad señorial trataba de conservar, evidentemente en su provecho, permanecía levemente ensombrecido por ciertas rivalidades entre la elite local. La profundidad de la polarización de ésta en bandos opuestos convertiría en inoperante el nuevo sistema de sorteo de los oficios y la pugna terminaría por devenir en lucha abierta a partir del asesinato de un antiguo procurador, Juan García Cermenal, entre 1423 y 1427, bajo el señorío del segundogénito de Fernando de Antequera, el infante don Juan de Aragón, rey de Navarra desde 1425. Sin embargo, la posición adoptada por el rey de Navarra e infante de Aragón difirió notablemente de la mantenida por su padre, al apoyar manifiestamente la postura de uno de los bandos, precisamente encabezado, entre otros, por Juan Alfonso Tomás y su pariente Diego Alfonso Tomás, personas vinculadas a la clientela del rey de Navarra, frente a sus contrarios ${ }^{83}$. La afinidad de esta facción permitió al infante don Juan la reintroducción de los corregidores y cuando, en 1427, por una ordenanza presentada al concejo por el corregidor Nuño Cabeza de Vaca, alférez mayor del rey de Navarra, prohibió bajo duras penas "fazer... ligas e monipolios e parçialidades con iuramento o syn iuramento" 84 que pudieran quebrantar las treguas alcanzadas en 1426, de hecho estaba respaldando el triunfo de sus fieles sobre el bando contrario, que se había opuesto ferozmente

se había efectuado la última ordenación de la documentación del archivo paredeño a finales de los años 90 del siglo XX. Por tanto, esta signatura es provisional y puramente indicativa, en previsión del destino final de estos fondos. Nuestras últimas noticias al respecto es que continúan depositados en Palencia.

${ }^{83}$ Diego Alfonso Tomás ya aparece en 1412 y 1413 en la contabilidad de Fernando I de Aragón como factor de su tesorero mayor en Castilla, Juan García de Paredes (Archivo de la Corona de Aragón. Maestre Racional, Real Patrimonio, Tesorería Real de Aragón. Tesorería del Rey, Libros Ordinarios, Vols. 415, f. 46 v., Vol. 416, ff. y 416, f. 102 v., 161 v.). La promoción de éste y su familia al servicio de los señores de Paredes fue extraordinarịa. Además de la presencia de Diego Alfonso y Juan Alfonso al frente de distintos oficios concejiles, Diego Alfonso era desde, al menos, 1424, recaudador del infante don Juan (J.C. MARTín CEA, El mundo rural, cit., pp. 140). À su vez, él y sus hijos disfrutaban de una merced de 2.400 mrs. sobre la yantar y la marzadga de Paredes y su esposa, Toribia Alfonso, había sido privilegiada con un descuento de $400 \mathrm{mrs}$. anuales en lo que hubiera de pechar por sus bienes en Paredes, como atestigua un asiento de las raciones, quitaciones y mercedes que el rey de Navarra tenía en Agradecemos a Susana Aparicio Rosillo que nos facilitara una copia de este excepcional documento). No es posible certificar si Diego Alfonso y Juan Alfonso son el caballero y ballestero, padre e hijo, que Martín Cea localizó en el alarde realizado en la villa en 1409 (J.C. MARTÍN CEA, El mundo rural, cit., pp. 137-141), pero sí es segura alguna relación de parentesco que permite vincular la prestancia de la familia dẹe caballeros urbanos Tomás con su integración en el servicio de Fernando de Antequera y su hijo. Por otro lado, podemos situar como afín, si no perteneciente, a la misma facción a la que pertenecían los Tomás a Fernán García Tablares, merino en 1423 (Ibidem, p. 60), presumiblemente pariente de Juan García Tablares, un prominente miembro de uno de los partidos durante el enfrentamiento de 1401-1403 y en 1412, al servicio armado del ya Fernando I de Aragón con una lanza (véase nota 34), si bien no consta que entre 1427-1429 Fernán García fuera hombre del rey de Navarra, no figurando como asentado en sus nóminas.

${ }^{84}$ AMPdN, 10004/02, Libro de Actas del Concejo, 1427-1428, sesión de 11 de abril. 
a cualquier forma de injerencia señorial en la resolución de un litigio que afectaba al equilibrio interno de poderes en el seno de la villa ${ }^{85}$.

Achacar esta conclusión del enfrentamiento al carácter autoritario y partidista del infante don Juan en comparación a la actitud conciliadora y respetuosa con la tradición foral de la villa de su padre Fernando en el contexto de 1401-1403 no dejaría de ser, en fin, una simplificación difícil de sostener a la luz de las evidencias que hemos manejado y, ante todo, de su análisis crítico. Las circunstancias habían cambiado a lo largo de veinte años. El balance de relaciones de la esfera señorial con las instancias urbanas se había modificado a partir de la integración de un sector de la elite local dentro del entorno social del sistema de poder señorial. Por tanto, la posición de la autoridad señorial ante las luchas internas por el control político del gobierno concejil, condicionada por su propio interés de asegurarse un dominio estable y respaldado por parte de sus vasallos del espacio bajo su jurisdicción, había de ser favorable a un orden público en que predominasen sus propios clientes.

\section{CONCLUSIONES}

A lo largo de estas páginas hemos procedido a desgranar los pormenores de un caso concreto de conflicto banderizo urbano en una villa señorial castellana a comienzo del siglo XV. Su análisis minucioso permite apreciar que la intervención de los señores en este tipo de pugnas se veía fuertemente condicionada por factores de diversa índole, como la propia naturaleza de los enfrentamientos, el equilibrio entre las fuerzas locales opuestas, el grado de organización interna de las mismas, el vigor de la comunidad y de sus instituciones frente a su posible mediatización por poderes externos o el nivel de asentamiento de los aparatos de dominación señorial en el ámbito municipal. Si las pretensiones señoriales pasaban por una garantía de gobierno estable en términos de orden social, eficiencia hacendística y disponibilidad militar y por el aumento de su capacidad de intervención en el sistema concejil para su consecución, las elites locales desarrollaban un complejo juego de, por un lado, atracción de la sanción señorial por parte de una facción hacia su hegemonía en el ámbito urbano frente a sus contrarios pero, por el otro, de mantenimiento de la independencia concejil frente a los controles externos. En consecuencia, la diversidad de objetivos perseguidos por los agentes ciudadanos, de una parte, y por el señorío, de la otra, conduce a reflexionar, en último término, sobre su armonización. La sofisticación de los recursos desplegados por los sistemas señoriales les permitía, en circunstancias como las descritas, bascular flexiblemente entre el ejercicio de la autoridad y el arbitraje esgrimiendo la defensa de principios políticos

\footnotetext{
${ }^{85}$ Este conflicto ha sido objeto de detallado estudio por el profesor Martín Cea. Véase, J.C. MARTÍN CEA, El mundo rural, cit., pp. 56-62, 216-218, 252-256; IDEM, Poderes públicos, cit., pp. 293-298; IDEM, Violencia y conflictividad, cit., pp. 130-132. Véase igualmente V. MUÑ̂Z comprensión del mismo y de los mecanismos de alineación política de las elites locales en liza.
} 
universalmente reconocidos, como eran la paz y el orden ${ }^{86}$. Su intromisión en las instituciones municipales de los lugares dominados, por tanto, a menudo adquiría un carácter limitado, en vistas a lograr la aprobación del ejercicio del señorío por sus vasallos mediante el reconocimiento de los espacios políticos de las elites locales. Es en este punto donde el desarrollo posterior de vías alternativas de penetración en el ámbito local, tales como la integración de las elites municipales en sus estructuras clientelares, podía venir a reajustar los equilibrios internos en las villas, construyendo nuevos escenarios para la imposición y el diálogo entre la esfera local concejil y la instancia superior señorial, favorables para una fracción del grupo social dominante en el espacio urbano pero sobre todo para el sistema de poder señorial.

\footnotetext{
${ }^{86} \mathrm{La}$ idea de la paz como ausencia de desórdenes es un concepto clave en el discurso político de la Castilla bajomedieval, habitualmente instrumentalizado desde el poder monárquico con el fin de para imponer su autoridad sobre las comunidades urbanas, como ha expuesto en su últimos trabajos Oscar LóPEZ GóMEZ (Claves del sistema de pacificación ciudadana desarrollado por los Reyes Católicos en Toledo (1475-1485), "En la España Medieval", 27 (2004), pp. 165-193; IDEM, Pas e sosyego". Un argumento de accion política en la Castilla bajomedieval, "Medievalismo", 16 (2006), pp. 46-71; IDEM, La sociedad amenazada. Crimen, delincuencia y poder en Toledo' a finales del siglo XV, Toledo, 2007. Junto a estas publicaciones, remitimos fundamentalmente a su monumental tesis doctoral inédita Violencia urbana y paz regia: el fin de la época medieval en Toledo (1465-1522), dirigida por Ricardo IZQUIERDO BENITO y defendida en la Universidad de Castilla La Mancha en 2006, donde se desarrolla en toda su intensidad esta línea de razonamiento). Como hemos evidenciado en este trabajo, el ámbito señorial también participaba de estas ideas y las manejaba en su propio provecho, del mismo modo que la Corona.
} 


\section{APÉNDICE DOCUMENTAL}

1402, agosto, 28, lunes - 30, miércoles. Paredes de Nava (1402, agosto, 22. Medina del Campo)

Declaración del concejo de Paredes de Nava, oponiéndose a recibir al corregidor enviado por el infante don Fernando, Sancho Fernández, el moço, de Medina del Campo, insertando su la carta de nombramiento, pese a haber sido acogido por los representantes de los bandos, y de la respuesta del corregidor suspendiendo las justicias de la villa y emplazando al concejo ante la Corte del infante.

AMPdN, Signaturas Antiguas-Documentos perdidos. Carpeta 01, no .50

Lunes, veynte e $<$ ocho $>{ }^{87}$ días de agosto, anno del Nasçimiento del Nuestro Saluador Ieshu Christo de mill e quatroçientos e dos annos, en persona de mí, Alfonso Ferrnández, notario por la abtoridad apostolical <e escriuano público enla uilla de Paredes de Naua por nuestro sennor el infante don Ferrnando $>$ e delos testigos deiuso escriptos, estando enla dicha villa de Paredes de Naua, estando el conçeio ayuntado acampana rrepicada enel portal dela eglesia de Santa Olalla, segúnd quelo an de vso e costumbre de se ayuntar, estando ý presentes Ferrnando Martínez, vachiller, e Martín Garçía, alcalldes, paresçió ý presente Sancho Ferrnández, el moço, e fizo leer enel dicho conçeio por mí, dicho notario, vna carta de nuestro sennor el infante, escripta en papel, firmada de su nombre e sellada con su sello de çera enlas espaldas, que es el tenor della este quese sigue:

De mí, el infante don Fernando, sennor de Lara, duque de Pennafiel e conde de Alborquerque e de Mayorga e sennor de Haro, al conçeio, alcalldes merinos, rregidores, caualleros e escuderos e omes buenos dela mi villa de Paredes de Naua e qualquier o qualesquier $/ /^{1 \mathrm{v}}$. de uos aquien esta mi carta fuere mostrada o el traslado della signado de escriuano público, salud e graçia.

Sepades que me es fecho entender que, enlos annos pasados fasta aquí, que han pasado e pasan enesa dicha mi villa algunas cosas non deuidas, las quales son contra todo derecho e iustiçia. E por quanto amí conviene de rremediar enlas tales cosas e poner castigo en aquel o aquellos que son culpados enlos tales malefiçios, mi merçed e voluntad es de enbiar e enbío aesa dicha mi villa aSancho Ferrnández, el moço, mi vasallo, vezino dela mi villa de Medina del Campo, por mi corregidor, por quanto el dicho Sancho Ferrnández es ome bueno de quien yo fío e tal que con iustiçia fará entodas las cosas lo que cumpliere ami seruiçio. Al qual do todo mi poder complido por esta mi carta para que oya e libre e conosca de todos los pleitos e contyendas çeuiles e creminales que han acaesçidos e acaesçieren de aquí adelante enesa dicha mi villa e ensus términos en quanto fuere mi merçed, e para corregir e enmendar los agrauios e syn rrazones que los alcalldes e merinos e iuezes que fueron e fueren enla dicha villa e otras personas fizieron e fezieren, e para fazer e complir las cosas que ellos fallesçieron e fallesçieren de fazer e complir, e para poder tomar los pleitos e contiendas que [t]ouieren començadas enel lugar e estado que estouieren e yr por [el]los adelante; e para que pueda poner alcallde e alcalldes por sí los que

\footnotetext{
${ }^{87}$ Siete] Ms., tachado.
} 
quisiere e entendiere que cumplen para que vusen ( $\mathrm{sic}$ ) delas dicha alcaldías por el tiempo e manera quelos el dicho corregidor posiere, e para que el dicho corregidor e los que poder touieren por él de iuzgar puedan dar sentençia o sentençias interlocutorias e defenetiuas, e fazer e mandar fazer esecuçión e esecuçiones dellas e de todas las otras cosas que deuieren ser fechas e esecutadas; para lo qual sobre dicho e para todas las otras cosas que alos dichos ofiçiales rrequieren, le do todo mi poder complido e mándouos que rreçibades al dicho mi corregidor e alos dichos alcalldes que él posiere venina mente, e vusedes (sic) conellos enlos dichos ofiçios e vengades asus enplazamientos e llamamientos sola pena e penas que ellos cada vno dellos posieren o mandaren poner. E defiendo firme mente que ninguno nin alguno non vusen (sic) delo dichos ofiçios $/^{2}$ nin de algunos dellos saluo el dicho mi corregidor e aquel e aquellos que por él poder ouieren. Que yo priuo dellos alos que fasta aquí los touieron e tienen.

Otrosí, do mi poder complido al dicho corregidor para que pueda fazer pesquisa e pesquisas sobre los rregidores e alcalldes e merinos que han seydo e son enesa dicha mi villa e sobre otra e otras personas, así general commo espeçial. E mando alos escriuanos que fueron e son enla dicha villa que den al dicho mi corregidor todas las acusaçiones e querellas e dettençiamientos e pesquisas que por ante ellos o por ante qual quier dellos pasaron con todo lo que sobre ellos fue fecho e signado de sus signos, para que el dicho mi corregidor lo pueda ver e faga sobre ellos lo que deuiere. E para que, si el dicho corregidor entendiere que cumple a mi seruiçio mandar que salgan desa dicha mi villa algunas personas e que non entren enella nin ensus términos por tiempo çierto so çierta pena, que lo pueda fazer.

Otrosí, vos mando que le acudades con todos los derechos que le pertenesçen al dicho ofiçio e le dedes buenas posada para él e para los suyos sin dineros. E es mi merçed e mando que dedes al dicho mi corregidor en quanto ý estudiese, aél e alos ${ }^{88}$ $<$ dichos $>$ sus alcalldes, sesenta maravedís para cada día para su costa e mantenimiento, contándole desde el día que de su casa partiere fasta que aella torne, contando los días del camino por rrazonables iornadas e siendo fenesçido e acabado el dicho su ofiçio de corregimiento. El qual dicho mantenimiento mando quele dedes luego en manera que él se pueda mantener dello; sinon, mando al dicho mi corregidor que prende e tome de vos bienes e los venda e se en ${ }^{89}$ trege delo que así ouiere de auer para el dicho su mantenimiento. E si para fazer e complir lo que dicho es e las otras $p^{2 v}$. cosas que el dicho corregidor e sus alcalldes e qual quier dellos ouieren de fazer e complir, e vos dixyeren que han menester vuestra ayuda, mando a vos, el dicho conçeio e omes bonos, e aqual quier deuos que llamados rrequeridos fuéredes para ello, que le ayudedes entodo lo que vos dixeren que ouieren menester vuestras ayudas solas penas que vos ellos e qual quier dellos pusieren, e so pena delos cuerpos e de quanto auedes.

E por esta mi carta tomo en mi guarda e en mi encomienda e seguro al dicho mi corregidor e alos sus ofiçiales e omes e cosas que conél fueren o estudieren, e defiendo que ninguno nin algunos non sean osados de voluer rroydo nin pelea conellos nin con alguno dellos nin fazer mal nin danno en sus cosas, sopena delos cuerpos e delos aueres. E mando al dicho mi corregidor que lo faga ansí apregonar pública mente por las plazas desa dicha villa por que todos sean aperçebidos delo guardar. E si alguno o algunos fueren o pasaren contra el dicho seguro e contra parte dél en dicho o en fecho o en conseio, mando al dicho mi corregidor e alos dichos sus alcalldes e

\footnotetext{
${ }^{88}$ Dichos] Ms., tachado.

${ }^{89}$ Rrege] Ms. tachado.
} 
aqual quier dellos que pasen contra ellos e contra cada vno dellos e contra sus bienes commo contra aquellos que pasan e quebrantan seguro puesto por su sennor.

E los vnos e los otros non fagades ende al, sopena dela mi merçed e de diez mill maravedís para la mi cámara a cada vno deuos por quien fincare delo así fazer e complir. E demás mando al dicho corregidor que vos enplaze que parescades ante mi do quier que yo sea, vos, el dicho conçeio, por vuestro procurador ${ }^{90}$, e vos, los dichos rregidores e ofiçiales, personal mente del día que vos emplazaren fasta seys días primeros seguientes, sola dicha pena acada vno, adezir por qué rrazón non cumplides mi mandado. E de cómmo esta mi carta vos fuere < mostrada $>$ e la cumpliéredes $^{91}$, mando al escriuano que para esto fuere llamado que dé ende, al que uos la mostrare, testimonio signado de su signo para que yo sepa cómmo cumplides mi mandado.

Dada enla mi villa de Medina del Campo, veynte e dos días de agosto, anno del nasçimiento del Nuestro Sennor Ieshu Christo de mill e quatroçientos e dos annos. mandado.

Yo, Pero Gonçález, escriuano del dicho sennor infante, la fiz escriuir por su

Yo, el Infante. (Rúbrica)

${ }^{3}$ La qual dicha carta del dicho sennor infante, mostrada enel dicho conceio, el dicho Sancho Ferrnández dixo que pedía e rrequería al dicho conçeio e omes buenos que cumpliesen dicha carta del dicho sennor infante segúnt que enella se contenía. E de commo dixo quelo dezía, que pedía e pedió amí, dicho escriuano, que gelo diese por testimonio signado de mi signo. E luego, el dicho conçeio e allcaldes e omes buenos dixieron que obedesçían e obedezieron la dicha carta del dicho sennor infante conla mayor rreuerençia que deuían, asý commo carta e mandadío de su sennor natural, al qual dixieron que mantouiese Dios a su seruiçio e dexare veuir por muchos tiempos e buenos, amén. E que auerían su conseio e que darían su rrespuesta.

Testigos que fueron presentes: Diego Alfonso notario, e Fernando Alfonso, e Pero Sánchez, e Iuan Martínez e otros.

Después desto, martes veynte e nueue días del dicho mes de agosto, anno dicho, en presençia de mí, dicho escriuano, e delos testigos de yuso escriptos, este día, estando el dicho conçeio ayuntado acampana rrepicada enel portal dela eglesia de Santa Olalla, segúnt quelo an de vso e de costumbre de se ayuntar, e estando presentes Ferrant Martínez, bachiller, e Martín Garçía Morate, e Iuan Garçía, alcalldes enla dicha villa, e Ferrant Garçía Cabras, e Iuan Garçía Tablares, procuradores del dicho con[çeio], e Iuan Ferrnández dela ...iota, e Diego Garçía Rromo, e Fernando Garçía, fiio de Ximón Pérez, e Alfonso Garçía Laso, e Ferrant Pérez, fiio de Martín G[arçía], e Alfonso Garçía dela Vid, e Alfonso Garçía, escriuano, rregidores dela dicha villa, e Pero Garçía, merino, e Iuan Ferrnández Cano, e Ferrant Garçía Lucas, e Pero Garçía, fiio de Toribio Ferrnández, e otros omes buenos, vezinos e moradores enla dicha villa; e luego el dicho conçeio e alcalldes e procuradores e rregidores, en nombre del dicho conçeio, dieron en rrespuesta ala carta del dicho sennor infante vn escripto en papel fecho enesta guisa:

El dicho conçeio, alcalldes e omes buenos, en dando rrespuesta ala carta del dicho sennor infante, dixieron quela obedesçían e obedesçerán conla mayor rreuerençia que podían e deuían, asý commo carta e mandado de su sennor natural, al qual dixieron que mantouiese Dios asu seruiçio e dexase veuir por muchos tiempos e buenos, amén. E dexieron quela dicha carta del dicho sennor infante, que era de

\footnotetext{
${ }^{90}$ Ms., borrón

${ }^{91} \mathrm{~A}$ los] Ms., tachado.
} 
obedesçer e non de cumplir, e por quanto $<$ dixieron $>$ que era e es agrauiada ${ }^{3 \mathrm{v}}$ e dada contra derecho común e contra la ley rreal e contra los preuilleios desta villa, por quanto el conçeio en la mayor parte dél nonlo pedió, segúnt que dixieron quelo entendýa mostrar ${ }^{92}$ al dicho sennor infante para quela su merçet lo enbiase mandar e declarar enla segunda iusyón pero que, entanto, dixieron que estaua el conçeio prestos para fazer mucha onrra al dicho Sancho Ferrnández e dele dar todas las cosas que mester ouiese para su prouimiento.

Esto dixieron que deuían e dieron por su rrespuesta.

E los dichos Pero Garçía merino, e Iohan Ferrnández Cano dixieron que bien sabía el dicho Sancho Ferrnández en cómmo ayer, lunes que pasó, que ellos e otros muchos, asý commo vezinos desta dicha villa e del conçeio della, paresçieron antél e le rresçebieran por corregidor segúnt quel dicho sennor infante mandaua, segúnt que dixieron que pasara por antel dicho ${ }^{93}$ Iohan Ferrnández Cano, escriuano desta dicha villa, e que agora eso mesmo dezían, quele rresçebían por ellos e por [to]dos los otros que conellos querrían ser.

E otrosí, los dichos Ferrant Garçía e Pero Garçía, por sý e por otros sus parientes e amigos que a ellos se quesiesen allegar, dixieron eso mesmo, quelo rresçebían e rresçebieron por corregidor segúnt quel dicho sennor infante mandaua, por ser obedientes a su mandamiento e non caer enlas penas contenidas enla dicha carta del dicho sennor infante.

$/{ }^{4}$ E luego, el dicho Sancho Ferrnández dixo < que por quanto los sobre dichos, quela dicha ${ }^{44}$ rrespuesta dada non complía a dicha carta del dicho sennor infante e quelos emplazaua que paresçieren antel dicho sennor infante al plazo e enla manera solas penas enla dicha carta contenidas. Otrosý dixo que $>$ por quanto el dicho sennor infante le diera poderýo del dicho corregimiento e iuzgado por su carta, por la qual carta priuara atodos los alcalldes que auían seydo e eran enla dicha villa, e la villa quedaua sin iustiçia. E sy asý estouiese non se podría cumplir mandado e seruiçio de nuestro sennor el Rrey e de nuestro sennor el infante. Otrosý, podría nasçer escándalo e mal enla dicha villa e quelo vno por esto, lo otro por quanto la mayor partida lo rresçebieran, por ende dixo que él que entendían vsar del dicho ofiçio de corrigymiento e vsar de iustiçia segúnt quele era mandado e dado poderío por el dicho sennor infante. E dixo que commo quier que al su ofiçio non ${ }^{95}<$ rrequeríe $>$ fazer iuramento $^{96}$ pero por más bastar, puso la mano derecha en vna sennal de Cruz e dixo que iuraua e iuró, a Dios e a Santa María e aquella sennal de Cruz e alas palabras delos Santos Euangelios do quier que están, quél que v[sará] bien $\mathrm{e}^{97}$ verdadera mente del dicho ofiçio e obedesçerá todos los mandamiento que nuestro sennor el Rrey e nuestro sennor el infante e cada vno dellos le fezieren por palabra o por carta o por mensaiero çierto. E, otrosý, que guardaría la onrra e sennorío e los derechos dellos e de cada vno dellos en todas cosas. Otrosý, que non descobrería en ninguna manera que ser pueda sus poridades. Otrosý, que donde viese su dapno, quelo desuiaría en todas guisas quél podiese o sopiese. E sy poder non oviese delo ffazer, que los aperçibiría dello lo más ayna que podiere. Otrosý, que libraría los pleitos que antél

\footnotetext{
${ }^{92}$ Antel] Ms., tachado.

${ }^{93} \mathrm{Ms}$., borrón

${ }^{94} \mathrm{Ms}$, , borrón

${ }^{95}$ Cumplíe] Ms., tachado.

${ }^{96}$ Por] Ms., tachado.

${ }^{97}$ Beal] Ms., tachado.
} 
veniese leal mente lo meior e más ayna quél podiese. Otrosý, que en quanto touiere el dicho ofiçio, que él nin otro por él non rresçebiría dineros nin prouisyón de ninguno que $/{ }^{4 v}$. ouiese mouido pleito antél o sopiese quelo ha de auer, nin de otro que gelo diese por rrazón dellos. Sy non, que Dios gelo demandase eneste Mundo al cuerpo e enel otro al alma commo aquel quese periura en su $<$ Santo $>$ Nombre. E dixo "Amén".

Testigos: Diego Alfonso notario, Alfonso Ferrnández Taiagrano, e Alfonso Garçía Tomás, e Iuan Cano, e Iohan Garçía presentes, e otros.

$1^{5}$ Después desto, < miércoles, XXX días del dicho mes del dicho anno, en presençia de mí, dicho notario, e delos testigos de yuso escriptos, estando $>$, el dicho conçeio, e alcalldes ${ }^{98}$, e ofiçiales, en rreplicando contra lo quelos delos dichos vandos dezían e Sancho Ferrnández dezían, dixieron:

Lo primero, que alo quelos delos dichos vandos dezían, que rresçebían al dicho Sancho Ferrnández por corrigidor, que fazían bien enlo rresçebir, pues los auían pedido al dicho sennor infante e lo auían menester.

Otrosý, dixieron que alo que dezían el dicho Sancho Ferrnández, que pues el dicho sennor infante priua alos alcalldes que aya enesta dicha villa, que non vsasen delos dichos ofiçios ${ }^{99}$, por lo qual fincaua la dicha villa sin iustiçia, e que sy asý estouiese, que se non cumplirían seruiçio del dicho sennor Rrey e del nuestro sennor el infante $\mathrm{e}^{100}$ que, por ende, que entend[ía] vsar del ofiçio del corrigymiento e otras cosas q[ue]1 [dich]o Sancho Ferrnández dixo por su rrespuesta, dixieron que ellos, por el dicho conçeio, que le non rresçebían nin rresçebieron por iuez e corrigidor dela dicha villa, por quanto non lo auían menester e tenían buen iuezes e alcalldes, e quel dicho sennor infante, quela carta diera non fuera formado enel fecho dela verdat nin la diera apeteçión del dicho conçeio, más quela diera $\mathrm{a}^{101}$ innestançia e petiçión delos dichos vandos. E que esos vandos lo ouiesen por iuez, que non el dicho conçeio, e le rrecudiesen conel dicho salario, $/^{5 \mathrm{v}}$ mas non el dicho conçeio; sobre lo qual escriuieran al dicho sennor infante quela su merçet fuese delos non dar iuez nin corrigidor alguno por quele non auían menester. E que, entanto, que rrequerýan e rrequerieron al dicho Sancho Ferrnández que non vsase de ofiçio de corregymiento alguno fasta quel dicho sennor infante lo sopiese e oviesen dél el segundo mandado. En otra manera dixieron que protestauan e protestaron delo non auer por iuez nin por corrigidor dela dicha villa e delo mostrar e querellar al dicho sennor infante, e quel dicho sennor infante proçediese contra él asý commo contra aquél que vsa de ofiçio e iustiçia non siendo rresçebido por el pueblo, e pasase contra é ${ }^{102}$ a aquellas penas como contra aquél que por su abtoridat se faze iuez.

E alo que dixo el dicho Sancho Ferrnández, que pues la mayor parte le rresçebía $^{103}$, por quela dicha villa non quedase por ( $\mathrm{sic}$ ) iuez, quél que entendía vsar del dicho corrigimiento, dixieron que dezía lo que por bien tenía e non era asý por que esos vandos que se dezían quele querían rresçebir non eran la diezma parte dela villa, por lo qual, según lo (sic) preuilleios $/{ }^{6}$ dela villa e segúnt derecho común e segúnt la

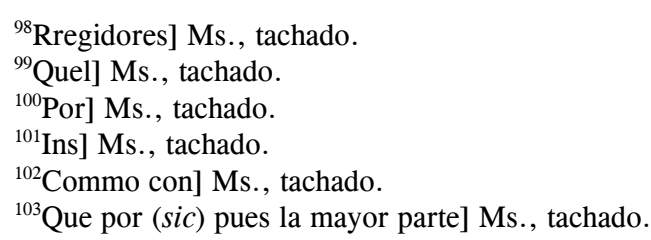


ley real, non deuía nin podía ser rresçebido por iuez. E esos que dezían quelo rresçebían por iuez, que esos le diesen el salario e non el conçeio.

E alo que dezía el dicho Sancho Ferrnández que enplazaua al conçeio e ofiçiales dela dicha villa por vertud dela carta del dicho sennor infante por quanto dezía quele non rresçebían por iuez, etcétera, dixieron quebien sabía el dicho Sancho Ferrnández que este enplazamiento que fazía ${ }^{104}$ non deuida mente por las rrazones que suso dicho auían, que pues él non deuía ser rresçebido por iuez dela villa e otrosý lo auían enbiado mostrar al dicho sennor infante, que fasta quel dicho sennor infante otra vegada les enbiase escriuir sobre ello, que non auían rrazón por quelos enplazar. Por ende, que protestauan e protestaron delo mostrar e querellar al dicho sennor infante segúnt que dicho auían e de auerse cobrar dél e de sus biennes aquella pena quel derecho pone contra aquellos que enplazan non deuida mente con todos los dapnos e menos cabos que sobre esta rrazón les veniesen e rrecresçiesen.

E que pedían a mí, dicho Alfonso Ferrnández, escriuano, que sy el dicho Sancho Ferrnández quesyese testimonio delo protestado, que gelo diese conesta rrespuesta, e al dicho conçeio otro abto para guarda de su derecho.

E luego, el dicho Ssancho Ferrnández dixo ser non presente / ${ }^{6 v}$. enlas protestaçiones que contra él fazían nin en algunos dellos. E dixo que pedía < lo que pedído auía $>{ }^{105}$ a mí, dicho notario, que gelo diese así signado con mío signo con todo lo pasado para guarda de lo mostrar al dicho sennor infante.

Testigos: Fernando Alfonso de Sant Çebrián, e ${ }^{106}$, e Iuan Garçía Lucas, e Iuan $^{107}$ (ilegible), notarios, e Diego Alfonso de Ţorre, e Martín Ferrnández pregonero.

Fecha de recepción del artículo: febrero 2009.

Fecha de aceptación y versión final: julio 2009.

\footnotetext{
${ }^{104}$ Que], Ms., tachado.

${ }^{105}$ Pedía] Ms., tachado.

${ }^{106}$ Ms., borrón.

${ }^{107}$ Alfonso Garçía], Ms., tachado.
} 